\title{
The development and nutritional characteristics of an omega-3-enhanced egg product
}

Nissan Michelle Kassis

West Virginia University

Follow this and additional works at: https://researchrepository.wvu.edu/etd

\section{Recommended Citation}

Kassis, Nissan Michelle, "The development and nutritional characteristics of an omega-3-enhanced egg product" (2009). Graduate Theses, Dissertations, and Problem Reports. 2798.

https://researchrepository.wvu.edu/etd/2798

This Thesis is protected by copyright and/or related rights. It has been brought to you by the The Research Repository @ WVU with permission from the rights-holder(s). You are free to use this Thesis in any way that is permitted by the copyright and related rights legislation that applies to your use. For other uses you must obtain permission from the rights-holder(s) directly, unless additional rights are indicated by a Creative Commons license in the record and/ or on the work itself. This Thesis has been accepted for inclusion in WVU Graduate Theses, Dissertations, and Problem Reports collection by an authorized administrator of The Research Repository @ WVU. For more information, please contact researchrepository@mail.wvu.edu. 


\title{
The Development and Nutritional Characteristics of an Omega-3-Enhanced Egg Product
}

\author{
Nissan Michelle Kassis \\ Thesis submitted to the \\ Davis College of Agriculture, Forestry, and Consumer Sciences \\ At West Virginia University \\ In partial fulfillment of the requirements \\ for the degree of \\ Master of Science \\ in \\ Human Nutrition and Food \\ Jacek Jaczynski, Ph.D., Chair \\ Kristen Matak, Ph.D. \\ Janet Tou, Ph.D.
}

Division of Human Nutrition and Foods

Morgantown, West Virginia

2009

Key words: omega-3 fatty acids, egg products, functional food products, egg sensory characteristics, egg nutritional composition, flaxseed oil, fish oil, algae oil, krill oil 


\title{
Abstract \\ The Development and Nutritional Characteristics of an
}

Omega-3-Enhanced Egg Product

\author{
Nissan Michelle Kassis
}

Novel, nutritionally-enhanced egg product was developed by substituting saturated fat and cholesterol-containing yolk with omega-3 fatty acids-rich ( $\omega-3 \mathrm{FA})$ flaxseed, menhaden, algae, and krill oils. The $\omega-3$ FA-fortified eggs are typically developed through alteration of hen feed. However, the present study aimed at creating such a product via processing. Experimental batters were developed to match composition, color, and texture of hen eggs (whole egg). The batters, whole egg, and liquid egg product (egg beaters) were cooked, analyzed, and compared. Moisture, protein, and fat content of experimental eggs matched ( $\mathrm{P}>0.05)$ whole egg.

Nutritionally, amino acid profile (AAP) analysis showed no significant differences in the ratio of essential amino acids to total amino acids (EAA/AA) when experimental eggs were compared to whole egg and egg beaters. Mineral profile (MP) analysis revealed that whole egg contained higher levels of $\mathrm{Ca}, \mathrm{P}$, and Fe than the experimental eggs, but $\mathrm{Mg}$ values were higher in experimental eggs (than whole egg) and comparable to egg beaters. Cholesterol content of the experimental eggs was significantly lower than that of whole egg $(\mathrm{P}<0.05)$. Fatty acid profile (FAP) analysis showed significantly higher percentages of n-3 PUFAs in the experimental eggs as compared to whole egg and a much lower $n-6 / n-3$ ratio in the experimental eggs than in whole egg $(\mathrm{P}<0.05)$. TBARS analysis showed that the rate of lipid oxidation of the experimental eggs (excluding krill eggs) was statistically less than or equal to that of whole egg, with the exception of krill eggs, despite the presence of omega-3 PUFAs. Color was analyzed using L*a*b* tristimulus color values, where $\mathrm{L}^{*}$ represents the lightness, $\mathrm{a}^{*}$ represents greenness or redness and $b *$ represents blueness or yellowness of a sample. The $L^{*}$ for experimental eggs was generally similar to whole egg except when krill oil was added. Experimental eggs had higher $(\mathrm{P}<0.05) \mathrm{a}^{*}$ and $\mathrm{b} *$ than whole egg and egg beaters, indicating more redness and yellowness, respectively. Texture profile analysis (TPA) values (hardness, springiness, cohesiveness, gumminess, chewiness, and resilience) revealed that experimental eggs had similar $(\mathrm{P}>0.05)$ and greater $(\mathrm{P}<0.05)$ textural properties when compared to whole egg and egg beaters, respectively. Fundamental torsion test confirmed that experimental eggs and whole egg had generally similar texture, but were firmer $(\mathrm{P}<0.05)$ than egg beaters. Kramer shear test indicated a $(\mathrm{P}>0.05)$ slightly firmer texture for experimental eggs than egg beaters. 


\section{Acknowledgements}

This project was funded by the WVU Research Corporation PSCoR Program and the USDA HATCH funds.

I would like to thank the faculty and staff in the Animal and Nutritional Sciences Department at West Virginia University for this opportunity, for their assistance, and for their continuous support. I would also like to thank my major advisor, Jacek Jaczynski, Ph.D. and my other committee members, Kristen Matak, PhD., and Janet Tou, Ph.D., for their availability and guidance. In addition, I would specifically like to thank Sarah Beamer for her selflessness, patience, and countless hours of help in the lab. I could not have done this without her. Also, a special thanks to Curran Gehring, who while working on his own thesis, took the time to assist with my statistical analysis. I would also like to recognize Joey Gigliotti, Ph.D. and Matt Davenport, Ph.D. for helping out with the methodology of the this project and being available to answer questions and address problems.

I would like to extend thanks to Jacek Jaczynski, Ph.D., my major advisor and project chair, who, without his continuous support and encouragement, would have made completing this project difficult. He always managed to be there to answer my questions and provide the feedback that I needed to keep me motivated and focused.

Finally, I want to thank my family and co-interns for their personal support, throughout this process. They were always there to listen and offer words of encouragement and praise. 


\section{Table of Contents}

Abstract................................................................

Acknowledgements.....................................................

Table of Contents......................................................

List of Figures........................................................

List of Tables.......................................................vii

Chapter I.............................................................

Overview.......................................................1

References.......................................................4

Chapter II........................................................... 5

Abstract........................................................6

Introduction....................................................8

Materials and Methods...............................................12

Results and Discussion.........................................21

Conclusion.......................................................32

References.....................................................33

Figures and Tables..............................................37 


\section{List of Figures}

\section{Chapter II}

Figure 1. Total essential amino acids (TEAA) content* of cooked whole egg and egg beaters was compared to cooked experimental eggs developed with addition of flaxseed, menhaden, algae (DHAS and DHASCO), and krill oils. * Data are given as mean values \pm standard deviation $(n=3)$. Different letters on the top of data bars indicate significant differences (Fisher's Least Significant Difference, $\mathrm{P}<0.05$ ) between mean values...

Figure 2. Total non-essential amino acids (TNonEAA) content* of cooked whole egg and egg beaters was compared to cooked experimental eggs developed with addition of flaxseed, menhaden, algae (DHAS and DHASCO), and krill oils. * Data are given as mean values \pm standard deviation $(n=3)$. Different letters on the top of data bars indicate significant differences (Fisher's Least Significant Difference, $\mathrm{P}<0.05$ ) between mean values...........46

Figure 3. Mineral (Ca, Mg, P, Fe) content* of cooked whole egg and egg beaters was compared to cooked experimental eggs developed with addition of flaxseed, menhaden, algae (DHAS and DHASCO), and krill oils. * Data are given as mean values \pm standard deviation $(\mathrm{n}=3)$. Different letters on the top of data bars indicate significant differences (Fisher's Least Significant Difference, $\mathrm{P}<0.05$ ) between mean values.

Figure 4. Cholesterol content* of cooked whole egg was compared to cooked experimental eggs developed with addition of flaxseed, menhaden, algae (DHAS and DHASCO), and krill oils. * Data are given as mean values \pm standard deviation $(n=3)$. Different letters on the top of data bars indicate significant differences (Fisher’s Least Significant Difference, $\mathrm{P}<0.05$ ) between

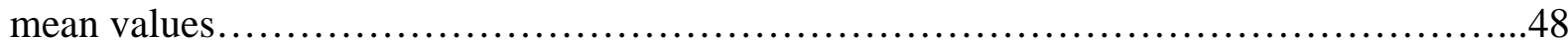

Figure 5. Percentage of specific fatty acid within total fatty acids of cooked whole egg was compared to cooked experimental eggs developed with the addition of flaxseed, menhaden, algae (DHAS and DHASCO), and krill oils. *Data are given as mean values \pm standard deviation $(\mathrm{n}=3)$. Different letters indicate significant differences (Fisher's Least Significant Difference, $\mathrm{P}<0.05$ ) between mean values.

Figure 6. Thiobarbituric acid reactive substances test (TBARS) measured lipid oxidation capacity of cooked whole egg compared to cooked experimental eggs developed with the addition of flaxseed, menhaden, algae (DHAS and DHASCO), and krill oils. Color absorbance was read at 532nm and TBARS values were reported as mg malondialdehyde (MDA) per kilogram of sample. *Data are given as mean values \pm standard deviation $(n=3)$. Different letters indicate significant differences (Fisher's Least Significant Difference, $\mathrm{P}<0.05$ ) between mean values. .50 
Figure 7. Kramer shear force* of cooked gels. Kramer force of cooked whole egg and egg beaters was compared to cooked experimental eggs developed with addition of flaxseed, menhaden, algae (DHAS and DHASCO), and krill oils. * Data are given as mean values \pm standard deviation $(\mathrm{n}=3)$. Different letters on the top of data bars indicate significant differences (Fisher's Least Significant Difference, $\mathrm{P}<0.05$ ) between mean values

Figure 8. Shear stress* and shear strain* of cooked gels. Shear Stress and strain of cooked whole egg and egg beaters were compared to cooked experimental eggs developed with addition of flaxseed, menhaden, algae (DHAS and DHASCO), and krill oils. * Data are given as mean values \pm standard deviation $(n=3)$. Different letters on the top of data points indicate significant differences (Fisher's Least Significant Difference, $\mathrm{P}<0.05$ ) between mean values within shear

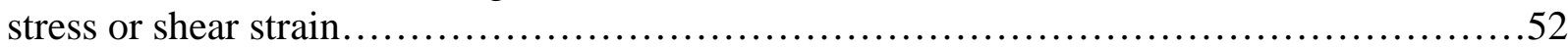

Figure 9. Hardness* (texture profile analysis) of cooked gels. Hardness of cooked whole egg and egg beaters was compared to cooked experimental eggs developed with addition of flaxseed, menhaden, algae (DHAS and DHASCO), and krill oils. * Data are given as mean values \pm standard deviation $(\mathrm{n}=3)$. Different letters on the top of data bars indicate significant differences (Fisher's Least Significant Difference, $\mathrm{P}<0.05$ ) between mean values 


\section{List of Tables}

\section{Chapter II}

Table 1. Proximate analysis* of cooked gels. Proximate composition of cooked whole egg and egg beaters was compared to cooked experimental eggs developed with addition of flaxseed, menhaden, algae (DHAS and DHASCO), and krill oils. * Data are given as mean values \pm standard deviation $(\mathrm{n}=3)$. Different letters within the same row indicate significant differences (Fisher's Least Significant Difference, $\mathrm{P}<0.05$ ) between mean values..........................54

Table 2. Essential amino acid (EAA) content* (g of EAA/100 g of sample, dry basis) of cooked whole egg and egg beaters was compared to cooked experimental eggs developed with addition of flaxseed, menhaden, algae (DHAS and DHASCO), and krill oils. The recommended values of EAA content for adults and infants are provided for comparison. * Data are given as mean values \pm standard deviation $(\mathrm{n}=3)$. Different letters within the same row indicate significant differences (Fisher's Least Significant Difference, $\mathrm{P}<0.05$ ) between mean values...............55

Table 3. Non-essential amino acid (NonEAA) content* (g of NonEAA/100 g of sample, dry basis) of cooked whole egg and egg beaters was compared to cooked experimental eggs developed with addition of flaxseed, menhaden, algae (DHAS and DHASCO), and krill oils. * Data are given as mean values \pm standard deviation $(\mathrm{n}=3)$. Different letters within the same row indicate significant differences (Fisher's Least Significant Difference, $\mathrm{P}<0.05$ ) between

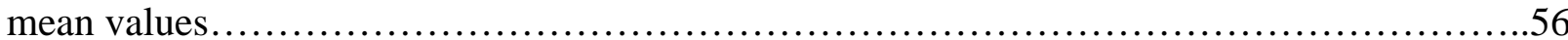

Table 4. Fatty acid ratios of cooked whole egg was compared to cooked experimental eggs developed with addition of flaxseed,menhaden, algae (DHAS and DHASCO), and krill oils. *Data are given as mean values \pm standard deviation $(\mathrm{n}=3)$. Different letters within the same row indicate significant differences (Fisher's Least Significant Difference, $\mathrm{P}<0.05$ ) between mean values

Table 5. Tristimulus color values* $\left(\mathrm{L}^{*} \mathrm{a} * \mathrm{~b} *\right.$ ) of cooked gels. Color values of cooked whole egg and egg beaters were compared to cooked experimental eggs developed with addition of flaxseed, menhaden, algae (DHAS and DHASCO), and krill oils. * Data are given as mean values \pm standard deviation $(n=3)$. Different letters within the same row indicate significant differences (Fisher’s Least Significant Difference, $\mathrm{P}<0.05$ ) between mean values. 
Table 6. Texture profile analysis* (TPA) of cooked gels. Texture profile of cooked whole egg and egg beaters was compared to cooked experimental eggs developed with addition of flaxseed, menhaden, algae (DHAS and DHASCO), and krill oils. * Data are given as mean values \pm standard deviation $(\mathrm{n}=3)$. Different letters within the same row indicate significant differences (Fisher's Least Significant Difference, $\mathrm{P}<0.05$ ) between mean values...........................59 


\section{Chapter I}

\section{Overview}

The functions of omega- 3 polyunsaturated fatty acids (n-3 PUFA), such as alphalinolenic acid (ALA, 18:3n-3), eicosapentaenoic acid (EPA, 20:5n-3), and docosahexaenoic acid (DHA, 22:6n-3) have been researched extensively. Omega3 fatty acids are vital building blocks of our cell membranes, signaling pathways and neurological systems. They play a critical role in many functions in the body and are essential for good health. Numerous studies have shown the beneficial health effects of n-3 PUFAs on cardiovascular health, immune function, neuronal development, and even in the prevention and treatment of chronic diseases such as arthritis, diabetes, osteoporosis, and certain cancers (Simopoulus, 1999; Vanek, 2007). However, it remains that the most widely researched health benefit of n-PUFAs is its cardio-protective effect.

Omega-3 PUFAs (as well as their n-6 counterparts) are essential nutrients in the human

body. ALA can be converted to EPA and DHA, however, humans are unable to synthesize ALA de novo, due to the lack of desaturase enzymes that add a double bond to the C-15 position of a fatty acid carbon (Surette, 2008). Furthermore, the conversion of ALA to EPA and DHA is relatively insufficient in humans. Therefore, ALA, EPA, and DHA are essential fatty acids that must be consumed in the diet. However, in the U.S., PUFAs constitute only about 7\% of total energy intake. Linoleic acid (LA,18:2n-6) compromises up to 89\% of total PUFA intake, whereas ALA typically only makes up about $10 \%$ of total PUFA energy intake in adult diets (Ursin, 2003). On average, the typical Western diet contains a 25:1 ratio of n-6/n-3 PUFAs, while the current recommendation is 4:1. An n-6 PUFA level greater than 5\% of the total daily energy consumption is undesirable (Drobná et al.). In humans, the conversion of LA to arachidonic acid (AA, 20:4n-6) is more efficient than that of ALA to EPA and DHA. Production 
of AA and EPA is further regulated by competition between LA and ALA for desaturase enzymes that catalyze their conversion to these long-chain fatty acids. Additional competition between AA and EPA for cyclooxygenases and lipoxygenases can substantially impact eicosanoid production. Eicosanoids derived from AA are proinflammatory and proaggregatory, and promote vasoconstriction and cell proliferation. By comparison, EPA-derived eicosanoids are less inflammatory and less proaggregatory (Kris-Etherton and Hill, 2008). Thus, a diet higher in ALA and EPA can limit overproduction of proinflammatory and proaggregatory eicosanoids.

Plant sources provide only ALA. ALA can be found in dark, leafy vegetables such as spinach and broccoli, walnuts, canola oil, and pumpkin seeds however, the most significant source of ALA is flaxseed oil. Both EPA and DHA are found prominently in fatty fish like salmon, tuna, mackerel, menhaden, and sardines. The main disadvantage of fish sources of n-3 PUFAs is that fish may be contaminated with toxins, which over time, can build up to unhealthy levels in the body and possibly reverse any health benefits associated with fish consumption (Thacker, 2004).

Fortunately, however, there is an expanding list of foods that are untraditional sources of n-3 PUFAs, such as cereals, drinks, baked goods, meats, and eggs that have been fortified with essential fatty acids. These so-called "nutraceuticals" or "functional" foods can be the means to achieve optimal health status by promoting the state of well-being and possibly reducing the risk of disease.

Eggs are of particular interest from a functionality viewpoint, because they are relatively rich in fatty acids and the associated fat-soluble compounds. However, the type and ratio of fatty acids is an important determinant of human health. The majority of fatty acids contained in an egg are saturated, which when consumed in excess in the diet, increase blood cholesterol, which 
can lead to increased risk for cardiovascular disease and stroke. Furthermore, one egg also contains approximately $200 \mathrm{mg}$ of cholesterol (Weggemans, Zock, \& Katan, 2001), which nearly meets the dietary cholesterol intake limit established by the American Heart Association at $\leq 300 \mathrm{mg} / \mathrm{d}$. Dietary cholesterol also increases serum total and LDL-cholesterol concentrations. Extensive research has been done on the enhancement of eggs with n-3 PUFAs in order provide the health benefits of n-3 PUFAS and also to reduce the saturated fat content of eggs. However, results show that although there is some increase in n-3 PUFA level, the level of cholesterol remains unchanged (Arantes da Silva, et al. 2008; Cobos, et al., 1995; Watkins and Elkin, 1992).

The aim of this study was to develop a cooked egg product that is not only rich in $\omega-3$ PUFA, but also has reduced cholesterol and saturated fat. We hypothesize that such an egg product can be developed via processing of eggs, by replacement of the yolk with n-3 PUFAs from various sources, rather than by enhancing chicken feed. The complete nutrient composition, along with texture and color properties of the resulting nutritionally-enhanced cooked egg products, were also compared to those of whole egg and a liquid egg product. 


\section{References}

Cobos, A., Delahoz, L., Cambero, M. I., Ordonez, J. A. (1995). Dietary modification and hen strain dependence of egg yolk lipids. Food Research International, 28, 71-76.

Kris-Etherton, P. M.; Hill, A. M. (2008). n-3 fatty acids: food or supplements? Journal of the American Dietetic Association, 108, 1125-1130.

Simopoulus, A. P. (1999). Essential fatty acids in health and chronic disease. American Journal of Clinical Nutrition, 70, 560S-569S.

Surette, M. E. (2008). The science behind dietary omega-3 fatty acids. Canadian Medical Association Journal. 178(2):177-180.

Thacker, P.D. (2004). Fish transport toxins hundreds of miles. Environmental Science and Technology, 38, 408A.

Ursin, V. M. (2003). Modification of plant lipids for human health: development of functional land-based omega-3 fatty acids. Journal of Nutrition, 133, 4271-4274.

Vanek, C.; Connor, W. E. (2007). Do omega-3 fatty acids prevent osteoporosis? American Journal of Clinical Nutrition, 85, 647-648.

Watkins, B. A.; Elkin, R. G. (1992). Dietary modulation of oleic and stearic acids in egg yolks. Journal of Food Composition and Analysis, 5, 209-215. 


\section{Chapter II}

The Development and Nutritional Characteristics of an Omega-3-Enhanced Egg Product 


\begin{abstract}
Novel, nutritionally-enhanced egg product was developed by substituting saturated fat and cholesterol-containing yolk with omega-3 fatty acids-rich ( $\omega$-3 FA) flaxseed, menhaden, algae, and krill oils. The $\omega-3$ FA-fortified eggs are typically developed through alteration of hen feed. However, the present study aimed at creating such a product via processing. Experimental batters were developed to match composition, color, and texture of hen eggs (whole egg). The batters, whole egg, and liquid egg product (egg beaters) were cooked, analyzed, and compared. Moisture, protein, and fat content of experimental eggs matched ( $\mathrm{P}>0.05)$ whole egg.

Nutritionally, amino acid profile (AAP) analysis showed no significant differences in the ratio of essential amino acids to total amino acids (EAA/AA) when experimental eggs were compared to whole egg and egg beaters. Mineral profile (MP) analysis revealed that whole egg contained higher levels of $\mathrm{Ca}, \mathrm{P}$, and Fe than the experimental eggs, but Mg values were higher in experimental eggs (than whole egg) and comparable to egg beaters. Cholesterol content of the experimental eggs was significantly lower than that of whole egg $(\mathrm{P}<0.05)$. Fatty acid profile (FAP) analysis showed significantly higher percentages of n-3 PUFAs in the experimental eggs as compared to whole egg and a much lower n-6/n-3 ratio in the experimental eggs than in whole egg $(\mathrm{P}<0.05)$. TBARS analysis showed that the rate of lipid oxidation of the experimental eggs (excluding krill eggs) was statistically less than or equal to that of whole egg, with the exception of krill eggs, despite the presence of omega-3 PUFAs. Color was analyzed using L*a*b* tristimulus color values, where $\mathrm{L}^{*}$ represents the lightness, $\mathrm{a}^{*}$ represents greenness or redness and $b *$ represents blueness or yellowness of a sample. The $L^{*}$ for experimental eggs was generally similar to whole egg except when krill oil was added. Experimental eggs had higher $(\mathrm{P}<0.05) \mathrm{a}^{*}$ and $\mathrm{b} *$ than whole egg and egg beaters, indicating more redness and yellowness,
\end{abstract}


respectively. Texture profile analysis (TPA) values (hardness, springiness, cohesiveness, gumminess, chewiness, and resilience) revealed that experimental eggs had similar $(\mathrm{P}>0.05)$ and greater $(\mathrm{P}<0.05)$ textural properties when compared to whole egg and egg beaters, respectively. Fundamental torsion test confirmed that experimental eggs and whole egg had generally similar texture, but were firmer $(\mathrm{P}<0.05)$ than egg beaters. Kramer shear test indicated a $(\mathrm{P}>0.05)$ slightly firmer texture for experimental eggs than egg beaters. 


\section{Introduction}

The egg is one of the best and most inexpensive sources of high quality protein and contains a balanced distribution of various vitamins and minerals relative to its low calorie content. For the last decade, American egg consumption has exceeded 6,000 million dozen eggs per year, rendering eggs an important staple food in most households (USDA, 2009a). Eggs contain all nine essential amino acids (EAA), making them an excellent source of high biological value (BV) protein and are frequently used as a reference for comparing the protein quality of other foods. Furthermore, eggs supply the diet with essential minerals such as calcium, phosphorus, iron, and magnesium. They are also one of the few exogenous sources of vitamins $\mathrm{K}$ and $\mathrm{D}$ as well as one of the few food sources that contain high concentrations of choline, a required nutrient that is essential for normal brain development (Herron \& Fernandez, 2004). However, one egg also contains approximately $200 \mathrm{mg}$ of cholesterol (Weggemans, Zock, \& Katan, 2001), which nearly meets the dietary cholesterol intake limit established by the American Heart Association at $\leq 300 \mathrm{mg} / \mathrm{d}$. Dietary cholesterol increases serum total and LDLcholesterol concentrations, which are established risk factors for cardiovascular disease (CVD) (Howell, McNamara, Tosca, Smith, \& Gaines, 1997). Furthermore, approximately half of the total fat content in an egg is saturated fat, another contributor to CVD (Hu et al., 1999).

Omega-3 polyunsaturated fatty acids ( $\omega-3$ PUFA) are one of a number of dietary components that have demonstrated cardio-protective benefits. In addition to the reduction of CVD, consumption of $\omega$-3 PUFA decreases triglyceride, blood pressure, and inflammatory markers, improves endothelial function, reduces platelet aggregation and vasoconstriction, and decreases risk of sudden cardiac death (Juturu, 2008). Fish, including farm-raised fish and their wild counterparts, are the major dietary sources of the longer-chain $\omega-3$ PUFAs, EPA and DHA 
Sources of plant-derived $\omega$-3 PUFA include flaxseed, flaxseed oil, walnuts, canola oil, soybean, and algae oil. Flaxseed oil is a rich source of ALA, while marine algae contains substantial amounts of DHA. Among populations in which total fat intake is considerably $>30 \%$ of total energy, yet mortality from CVD is low, fish and plant oils are the primary sources of fat consumed (Psota, Gebauer, \& Kris-Etherton, 2006).

However, despite the fact that adequacy of $\omega$-3 PUFA intake is beneficial to human health, the American diet is typically low in this nutrient (Arterburn, Oken, Hall, Hamersley, Kuratko, \& Hoffman, 2008). This has promoted the progressive production of "nutraceutical/functional foods" or those that contain added, technologically developed ingredients that have specific health benefits (Siro, Kapolna, Kapolna, \& Lugasi, 2008). The $\omega$ 3 PUFA-fortified food products provide a means to achieve desired biochemical effects of these nutrients without the ingestion of dietary supplements, medications, or a major change in dietary habits. Unfortunately, a consequence of the addition of PUFAs to food, is the susceptibility of their double bonds to oxidative deterioration, which can be potentially responsible for the formation of peroxides and off-flavors, changes of texture and color, loss of nutrients, and production of toxic compounds (Franchini, Sirri, Tallarico, Minelli, Iaffaldano, \& Meluzzi, 2002).

Dietary manipulation of the $\omega$-3 PUFA content of hens'diets has resulted in the production of eggs containing $\omega-3$ PUFA (Ferrier, Caston, Leeson, Squires, Weaver, \& Holub, 1995). In acceptability studies, U.S. consumers responded positively to $\omega$-3- fortified eggs (Scheideler, Froning, \& Cuppett, 1997). However, consumers may be reluctant to consume eggs as a source of $\omega$-3 PUFA due to their high cholesterol and saturated fat contents (Weggemans et al., 2001; Hu et al., 1999). Furthermore, adding $\omega$-3-rich ingredients such as flaxseed, algae, 
kelp, fish oil, and canola oils to chicken feed produces eggs with three or more times the normal amount of $\omega-3$ PUFA; however, an egg is not naturally rich in $\omega-3$ FA. Therefore, even a threefold increase should be considered relatively small, particularly when compared with the recommended daily intake for $\omega-3$ PUFA by the governments of Canada, Scandinavia, and Britain, which recommend between 1,000 and 2,000 mg/d. The U.S. has not yet set a recommended daily intake for $\omega$-3 PUFA.

Arantes da Silva et al. (2008) demonstrated incorporation of $\omega$-3 PUFA into quail egg yolks by altering levels of flaxseed in the feed. Although results showed a reduction in total saturated FA content, in addition to an increase in PUFA in some treatments groups, no difference was found in cholesterol levels between all groups. Thus, even though nutritionallyenhanced eggs via alteration of hens’ diets may contain less saturated fat, their cholesterol content remains unchanged.

There are, however, many liquid egg products and egg substitute products on the market, such as Egg Beaters ${ }^{\mathrm{TM}}$ that do not contain saturated fat or cholesterol. Although, these types of products, while relatively high in protein and low in calories, often do not gain consumer acceptability due to sensory quality when compared to that of regular eggs (Leutzinger, Baldwin, \& Cotterill, 1977). In addition, these products do not contain $\omega-3$ PUFA; and therefore, lack the potential health/nutraceutical and marketing benefits.

The objective of this study was to develop a cooked egg product that is not only rich in $\omega$-3 PUFA, but also has reduced cholesterol and saturated fat. We hypothesize that such an egg product can be developed via processing of eggs, rather than by enhancing chicken feed. The investigation reported here was aimed specifically at determination of nutrient composition, including amino and fatty acid profile analysis, cholesterol and mineral profiles, as well as 
texture and color properties of nutritionally-enhanced cooked egg products developed by removal of the cholesterol-containing yolk and the addition of $\omega$-3 PUFA from alternative sources, including flaxseed, menhaden, krill, and algae oils. The complete nutrient composition, along with texture and color properties of the resulting nutritionally-enhanced cooked egg products, were also compared to those of whole egg and a liquid egg product. 


\section{Materials and Methods}

\section{Development of Experimental Batters}

Fresh, store brand eggs were purchased from a local chain grocery store. For comparison, top national brand liquid egg product (hereafter called “egg beaters”) was also purchased from the same store. The eggs and egg beaters were stored under refrigeration and the storage time did not exceed three days. The experimental egg batters consisted of fresh egg whites, alternative oil, freeze-dried egg whites, non-iodized salt $(\mathrm{NaCl})$, and annatto. The egg whites were manually separated from whole eggs. The yolks were not used in the experiments. Care was taken to remove chalaza membrane from egg whites. Annatto (cheese coloring CM500A) was obtained from Grape and Granary (Akron, OH). Annatto is a plant derived yellow pigment with amphiphilic properties allowing for simultaneous water- and lipidsolubility. Therefore, annatto was used to obtain a color of the experimental egg products that would resemble the color of whole (i.e., egg yolk and white mixed together) cooked egg. The following alternative oils were used in the formulation of experimental egg products:

1) Flaxseed oil was obtained from Jedwards International, Inc. (Quincy, MA).

2) Menhaden oil (Omega Pure 8042TE) was obtained from Omega Pure (Reedsville, VA).

3) Algae oil (DHAS) was obtained from Martek Biosciences (Columbia, MD).

4) Algae oil (DHASCO) was obtained from Martek Biosciences (Columbia, MD).

5) Krill oil (4225F) was obtained from Enzymotec USA, Inc. (Springfield, NJ).

The objective for the formulation of experimental egg products was to achieve moisture, crude protein, and total fat that would be comparable to the proximate composition of whole egg. An optimization spreadsheet was set up and preliminary experiments (data not shown) were conducted to meet this objective. The optimized batter composition of the experimental egg 
products containing all of the above alternative oils except the DHASCO algae oil was as follows:

1) $430 \mathrm{ml}$ of fresh egg whites.

2) $50 \mathrm{ml}$ of alternative oil (4 alternative oils listed above).

3) $15 \mathrm{~g}$ freeze-dried egg whites.

4) 5 g non-iodized salt $(\mathrm{NaCl})$.

5) $750 \mu$ annatto.

The batter composition that included the DHASCO algae oil included $420 \mathrm{ml}$ of fresh egg whites, $40 \mathrm{ml}$ of DHASCO oil, $20 \mathrm{~g}$ of soybean lecithin (catalog number 03376-250, Fisher

Scientific, Fairlawn, NJ), $15 \mathrm{~g}$ of freeze dried egg whites, $5 \mathrm{~g}$ of non-iodized salt ( $\mathrm{NaCl}$ ), and 750 $\mu \mathrm{l}$ of annatto. It was found in the preliminary experiments (data not shown) that $20 \mathrm{~g}$ of soybean lecithin prevented phase separation and following cooking, the resultant gels were uniform. The DHAS oil contained lecithin. The same fresh egg whites were used for freeze-drying (VirTis Genesis 35SQ Super XL freeze-dryer, Virtis, Gardiner, NY) as the fresh egg whites used in the batter formulation. The freeze-dried egg whites were added in order to increase crude protein content in the experimental batter so that it would be comparable to that of whole egg (i.e., egg yolk and white mixed together). Final volume was approximately $500 \mathrm{ml}$.

\section{Mixing and cooking of experimental batters, mixed whole egg, and egg beaters}

The $500 \mathrm{ml}$ of batter, whole egg (i.e., egg yolk and white), or egg beaters was mixed in a $1 \mathrm{~L}$ beaker. However, approximately $18 \mathrm{~h}$ prior to addition of the other ingredients, the $15 \mathrm{~g}$ of freeze-dried egg whites were added to the $430 \mathrm{ml}$ fresh egg whites (or $420 \mathrm{ml}$ when the DHASCO algae oil was used) and held under refrigeration. Mixing was not used during these 18 h. It was determined in the preliminary experiments (data not shown) that this procedure 
allowed hydration of freeze-dried egg whites and following cooking the resultant gels were uniform. Following $18 \mathrm{~h}$ of hydration, all other ingredients were added and the experimental batters were mixed for $2 \mathrm{~h}$ at room temperature, while whole egg and egg beaters for $1 \mathrm{~h}$ also at room temperature. The beaker was placed on a mixing plate (Thermix Strirring Hot Plate Model 310T, Fisher Scientific, Fairlawn, NJ) with a standard 3-inch magnetic stir bar. It was determined in the preliminary experiments (data not shown) that these mixing procedures prevented phase separation and following cooking, the resultant gels were uniform. Following mixing, the batter, mixed whole egg, or egg beaters was poured into tubes and cooked.

For texture profile analysis (TPA), Kramer shear test, and color properties (see below) the batter, mixed whole egg, or egg beaters was stuffed into polycarbonate tubes (length $=18$ $\mathrm{cm}$, internal diameter $=1.90 \mathrm{~cm}$, wall thickness $=0.635 \mathrm{~cm}$ ). The tubes had polycarbonate screw caps at both ends that were sealed with standard o-rings. The tubes were placed in a standard 1100 Watt household microwave oven (Model JES1139WL, GE Appliances, Louisville, KY) set at 50\% power and the experimental batter, mixed whole egg, or egg beaters was cooked for $60 \mathrm{~s}$. Preliminary experiments (data not shown) showed that these settings were optimal for gelation of the batter, mixed whole egg, and egg beaters, resulting in uniformly cooked gels without over- or under-cooking.

For torsion test, the batter, mixed whole egg, or egg beaters was poured into teflon-coated stainless steel pre-molded torsion tubes (Chen and Jaczynski, 2007a; 2007b; Taskaya, Chen, \& Jaczynski, 2009a; 2009b). These pro-molded tubes allow simultaneous cooking of six torsion samples. Following cooking each torsion sample has an hourglass cylindrical shape (length $=$ $2.54 \mathrm{~cm}$, end diameter $=1.90 \mathrm{~cm}$, and midsection diameter $=1.0 \mathrm{~cm})$. These dimensions and shape are required for torsion test (Kim, Park, \& Yoon, 2005). The tubes had stainless steel 
screw caps at both ends. The tubes were placed in a standard circulating water bath (Model 260 Circulating Bath, Precision, Winchester, VA) set at $90^{\circ} \mathrm{C}$ and the batter, mixed whole egg, or egg beaters was cooked for $10 \mathrm{~min}$. Preliminary experiments (data not shown) showed that these setting were optimal for gelation of the batter, mixed whole egg, and egg beaters, resulting in uniformly cooked gels without over- or under-cooking.

\section{Proximate composition analysis of cooked gels}

The moisture content, total fat, crude protein, and ash content were determined for cooked gel samples (i.e., from the experimental batters, mixed whole egg, or egg beaters). For moisture determination, sample (2 g) was placed on an aluminum dish (Fisher Scientific Co., Fairlawn, NJ), spread evenly across the dish and oven-dried $\left(105^{\circ} \mathrm{C}\right.$ for $\left.24 \mathrm{~h}\right)$ (AOAC, 1995). Total fat content was determined according to the Soxhlet extraction method (AOAC, 1995) and expressed as g/100g (dry weight basis). Crude protein was determined by Kjeldahl assay (AOAC, 1995) and expressed as g/100g (dry weight basis). Ash content was performed by incinerating samples in a muffle furnace at $550^{\circ} \mathrm{C}$ for $24 \mathrm{~h}$ (AOAC, 1995) and expressed as g/100g (dry weight basis). All proximate analyses are reported as mean values of at least three replicates.

\section{Amino acid profile analysis.}

The cooked gel samples (i.e., from the experimental batters, mixed whole egg, or egg beaters) were analyzed for a full amino acid profile (AAP) according to the AOAC method 982.30 E (a, b, c) (AOAC, 1995). The cooked gel samples were freeze-dried and subjected to the following three types of hydrolysis: acid hydrolysis with $6 \mathrm{~N} \mathrm{HCl}$ at $110^{\circ} \mathrm{C}$ for $24 \mathrm{~h}$, performic acid oxidation at $0-5^{\circ} \mathrm{C}$ overnight followed by acid hydrolysis $\left(6 \mathrm{~N} \mathrm{HCl}\right.$ at $110^{\circ} \mathrm{C}$ for $24 \mathrm{~h}$ ), and alkaline hydrolysis with fresh $4.2 \mathrm{~N} \mathrm{NaOH}$ at $110^{\circ} \mathrm{C}$ for $22 \mathrm{~h}$. Following the 
hydrolysis, amino acids were quantified using the Beckman Amino Acid Analyzer (model 6300, Beckman Coulter, Inc., Fullerton, CA) employing sodium citrate buffers as step gradients with the cation exchange post-column ninhydrin derivatization method (Chen et al., 2007; Chen et al., 2008; Taskaya et al., 2009; Gigliotti et al.,2008). The data are reported as mean values ( \pm standard deviation) of at least three replicates and the mean values are expressed as $\mathrm{g}$ of amino acid per $100 \mathrm{~g}$ of sample (dry weight basis).

\section{Mineral profile analysis.}

The cooked gel samples (i.e., from the experimental batters, mixed whole egg, or egg beaters) were analyzed for mineral profile (MP) (Chen et al., 2007; Chen et al., 2008; Taskaya et al., 2009). All glassware was washed overnight in a solution of $10 \% \mathrm{HCl}$ in distilled and deionized water (dd $\mathrm{H}_{2} \mathrm{O}, \mathrm{v} / \mathrm{v}$ ) prior to use. Ashed samples were dissolved in $2 \mathrm{~mL}$ of $70 \%$ nitric acid. The acidified samples were neutralized in $5 \mathrm{~mL}$ of dd $\mathrm{H}_{2} \mathrm{O}$ and filtered through Whatman no. 1 paper. Samples were diluted to volume with $\mathrm{dd}_{2} \mathrm{O}$ in a $50 \mathrm{~mL}$ volumetric flask. Major minerals, calcium (Ca), magnesium (Mg), and phosphorus (P), as well as a minor mineral iron (Fe) were determined using inductively coupled plasma optical emission spectrometry (model P400; Perkin Elmer, Shelton, CN, USA). The data are reported as mean values of at least three replicates and expressed as mg per $100 \mathrm{~g}$ of sample (dry weight basis).

\section{Cholesterol profile.}

The cooked gel samples (i.e., from the experimental batters, mixed whole egg, or egg beaters) were analyzed for cholesterol content according to the AOAC method 994.10 (14). The cooked gel samples were freeze-dried and subjected to saponification at high temperature with ethanolic $\mathrm{KOH}$ solution. The unsaponifiable fraction containing cholesterol and other sterols 
was then extracted with toluene. Sterols were derivatized to trimethylsilyl (TMS) ethers and then quantified by gas chromatography.

\section{Fatty acid profile analysis.}

Fatty acid profile was performed in triplicate at the University of Missouri-Columbia according to the Association of Official Analytical Chemists methods (1995). Fat and fatty acids were extracted from biomass by the acidic hydrolysis method (AOAC 996.06). Pyrogallic acid was added to minimize oxidative degradation of fatty acids during analysis. Triglyceride, triundecanoin (C11:0), was used as internal standard. Fat was extracted into ether, then methylated to fatty acid methyl esters (FAMEs) using boron trifluoride (BF3) in methanol. FAMEs were quantitatively measured by capillary gas chromatography against the C11:0

internal standard. All samples were analyzed on a gas-liquid chromatography (Agilent Technologies, Model 7890A) equipped with a 7683B series Injector. Helium was used as the carrier gas with a $0.75 \mathrm{~mL} / \mathrm{min}$ flow rate. The temperature program for separations began at $100^{\circ} \mathrm{C}$, held for $4 \mathrm{~min}$, increased to $240^{\circ} \mathrm{C}$ at $3^{\circ} \mathrm{C} / \mathrm{min}$ and held for $15^{\circ} \mathrm{C}$. Temperatures for injector and detector were 225 and $285^{\circ} \mathrm{C}$ respectively. Peaks were identified by comparing their retention times with references. Total fat was calculated as sum of individual fatty acids expressed as triglyceride equivalents.

\section{Thiobarbituric acid reactive substances (TBARS) test.}

Lipid oxidation was quantified in freeze-dried samples of whole egg and experimental eggs using the thiobarbituric acid reactive substances (TBARS) test. Samples were tested in triplicate using the TBARS test described by Yu and Sinnhuber (1957). The color absorbance was read at $532 \mathrm{~nm}$, and the TBARS value was calculated using the following equation: Sample TBARS = Ks x A x 5 / Wt (A = absorbance of sample, Wt = exact sample weight, Ks = constant 
obtained from the slope of the standard curve.) The results were reported as mg malondialdehyde per kg sample.

\section{Texture properties of cooked gels}

Three different methods were employed to determine texture: torsion test, Kramer shear test, and texture profile analysis (TPA). Although these three texture measurements are commonly employed for determination of textural properties, each method provides slightly different information. Torsion test is considered a fundamental test for texture, while Kramer shear test and TPA are empirical tests (Kim et al., 2005). Likely, the most comprehensive understanding of textural properties is provided by a combination of the fundamental and empirical tests. Therefore, these three different tests were employed in the present study.

Shear stress and shear strain of cooked gels (i.e., from the experimental batters, mixed whole egg, or egg beaters) was determined using torsion test (Jaczynski and Park, 2004; Chen and Jaczynski, 2007a; 2007b; Taskaya et al., 2009a; 2009b). The gels were equilibrated to room temperature for $2 \mathrm{~h}$ prior to the measurement. At least five hourglass cylindrical gels (length $=$ $2.54 \mathrm{~cm}$, end diameter $=1.90 \mathrm{~cm}$, and midsection diameter $=1.0 \mathrm{~cm}$ ) per treatment were glued to plastic discs and subjected to torsional shear using a Hamman Gelometer (Gel Consultant, Raleigh, NC) set at $2.5 \mathrm{rpm}$. Shear stress and shear strain at mechanical fracture were measured to determine gel strength and gel cohesiveness, respectively.

At least five cooked gels (i.e., from the experimental batters, mixed whole egg, or egg beaters) (length $=8.0 \mathrm{~cm}$, diameter $=1.9 \mathrm{~cm}$ ) were subjected to Kramer shear test using a texture analyzer (Model TA-HDi, Texture Technologies Corp., Scarsdale, NY) equipped with a Kramer cell attachment. Kramer shear cell consisted of five 3.0-mm thick and 70-mm wide shear blades passing through a cell having a corresponding number of slots. Individual gel samples were 
weighed and placed under the blades in the Kramer cell. Shear force was measured at a 127 $\mathrm{mm} / \mathrm{min}$ crosshead speed and expressed as maximum peak force (g peak force / $\mathrm{g}$ of gel sample) (Chen and Jaczynski, 2007a; 2007b; Taskaya et al., 2009a; 2009b; Taskaya, Chen, Beamer, \& Jaczynski, 2009c).

Texture profile analysis (TPA) of cooked gels (i.e., from the experimental batters, mixed whole egg, or egg beaters) was performed according to Cheret, Chapleau, Delbarre-Ladrat, Verrez-Bagnis, \& Lamballerie (2005). The gel samples at room temperature were subjected to two-cycle compression at 50\% using the texture analyzer (Model TA-HDi, Texture Technologies Corp., Scarsdale, NY) equipped with a 70-mm TPA compression plate attachment moving at a speed of $127 \mathrm{~mm} / \mathrm{min}$. From the resulting force-time curves, hardness, springiness, cohesiveness, gumminess, chewiness, and resilience were determined (Chen and Jaczynski, 2007a; 2007b; Taskaya et al., 2009a; 2009b; 2009c). The definitions of the TPA parameters are as following: (1) hardness indicates the maximum force required to compress a sample; (2) springiness indicates ability of sample to recover its original form after the deforming force is removed; (3) cohesiveness corresponds to the extent to which the sample can be deformed before rupture; (4) gumminess is the force required to disintegrate a semisolid sample to a steady state of swallowing (hardness x cohesiveness); (5) chewiness is related to the work needed to chew a solid sample to a steady state of swallowing (springiness x gumminess); (6) resilience shows how well a sample resists to regain its original position. At least five cylindrical gels (length $=2.54 \mathrm{~cm}$, diameter $=1.90 \mathrm{~cm}$ ) per treatment were used for the TPA.

\section{Color properties of cooked gels}

The cooked gel samples (i.e., from the experimental batters, mixed whole egg, or egg beaters) were equilibrated to room temperature for $2 \mathrm{~h}$ prior to the color measurements. Color 
properties of cooked gels were determined using a Minolta Chroma Meter CR-400 colorimeter (Minolta Camera Co. Ltd., Osaka, Japan). At least seven cylindrical gels (length $=2.54 \mathrm{~cm}$, diameter $=1.90 \mathrm{~cm}$ ) per treatment were used for color measurement. A CIE color system using L*a*b* tristimulus color values were determined (Chen and Jaczynski, 2007a; 2007b; Taskaya et al., 2009a; 2009b; 2009c).

\section{Statistical Analysis}

The experiments were triplicated $(n=3)$. In each triplicate, at least three measurements were performed for proximate analysis (i.e., moisture content, total fat, crude protein, and ash content) and nutrition composition (i.e., AAP, FAP, and MP), at least five measurements were performed for determination of texture properties (i.e., torsion test, Kramer shear test, and TPA), and at least seven measurements were performed for determination of color properties (i.e., L*a*b*). Data were subjected to one-way analysis of variance (ANOVA). A significant difference was used at 0.05 probability level and differences between treatments were tested using the Fisher’s Least Significant Difference (LSD) test (Freud \& Wilson, 1997). The statistical analysis was performed using R version 2.0.9 software (Ihaka and Gentleman, 1996). The data are reported as mean values \pm standard deviation (SD). 


\section{Results and Discussion}

\section{Proximate analysis}

The proximate composition following cooking of the experimental eggs was compared to that of cooked whole egg and cooked egg beaters (Table 1). The moisture content, crude protein, and total fat of the experimental eggs were similar $(\mathrm{P}>0.05)$ to those of whole egg. This result was expected since the batters of the experimental eggs were formulated to match the proximate composition of whole egg. Protein and fat are essential dietary macronutrients and eggs contain nearly equal amounts of both. One egg contains approximately $6 \mathrm{~g}$ of protein, over half of which is in the egg white, and $5 \mathrm{~g}$ of fat, all contained within the yolk. Removing the yolk not only eliminated the egg total fat content, but also reduced the protein content, thus freezedried egg whites were added to the experimental batters to match the protein content of whole egg. Digestibility of egg protein is approximately 97\%, meaning that approximately $97 \%$ of egg

protein is absorbed as AA, which are essential for new protein synthesis and replacement of lost protein (Bodwell, Satterlee, \& Hackler, 1980). The fat content of the experimental batters was solely derived from $\omega$-3-rich oils which was comparable to the total lipid content of whole egg. Although egg yolks do contain some PUFA, the majority of the total fat content in eggs is saturated, which is known to increase risk of heart disease when consumed in excess in the diet. Thus, the saturated fat (and cholesterol) in whole egg was replaced with heart-healthy $\omega$-3 PUFA.

Furthermore, fat influences texture of food products (mouth-feel, hardness, chewiness, etc.) and is also typically considered as a carrier of lipophilic flavors and aromatic compounds. At the same time, food proteins undergo gelation when subjected to heat, resulting in texture development. Following cooking, protein gel matrix also traps fat molecules along with the 
lipophilic flavors and aromatic compounds. Therefore, protein content directly affects several textural parameters in addition to indirect effect on food flavor and aroma. Consequently, fat and protein in a food product collectively contribute to sensory quality of that product and as a result, fat and protein content influence consumers' perception. The moisture content is also important since water in food products provides reaction medium. Water is also considered a pre-requisite for protein gelation; and therefore, proper texture development. This is why one of the objectives of the present study was to match $(\mathrm{P}>0.05)$ total fat, crude protein, and moisture content of the experimental eggs to those of whole egg (white and yolk mixed together). As confirmed by statistical analysis of the proximate composition, this objective was met.

The USDA reports proximate composition of whole egg as 75.8, 47.4, 41.0, and 3.7 g/100g for moisture, crude protein, total lipid, and ash, respectively (USDA, 2009b). The proximate composition of the experimental eggs developed in this study and the whole egg used as a control are similar to the composition data reported by the USDA (USDA, 2009b). However, it is important to note that egg beaters had different $(\mathrm{P}<0.05)$ proximate composition than the experimental eggs and whole egg. Egg beaters had higher $(\mathrm{P}<0.05)$ moisture content and crude protein (on dry weight basis) as well as lower $(\mathrm{P}<0.05)$ total fat (on dry weight basis) than experimental eggs and whole egg. However, the crude protein and total fat content on wet basis (often referred to as "as-is" basis, data not shown but can be calculated from Table 1) for egg beaters were 9.9 and $0.3 \mathrm{~g} / 100 \mathrm{~g}$, respectively; while the corresponding average values for the experimental eggs and whole egg were 13.8 and $10.9 \mathrm{~g} / 100 \mathrm{~g}$, respectively. Therefore, these differences in proximate composition of egg beaters may translate into differences in the texture and flavor. This data is consistent with the fact that the base ingredient for egg beaters are egg whites that are void of fat and have higher moisture content when compared to whole egg. 
The ash content of the experimental eggs was similar $(\mathrm{P}>0.05)$ to that of egg beaters and higher $(\mathrm{P}<0.05)$ than that of whole egg. A possible explanation is that the addition of the non-iodized salt, annatto, and freeze-dried egg whites may have contributed to higher ash content in the experimental gels than in whole egg. Furthermore, egg beaters also contain added salt and colorings, in addition to other additives such as thickening agents and preservatives. This is likely why the ash content of the experimental eggs was similar to egg beaters.

\section{Amino acid profile analysis.}

Proximate analysis of the cooked egg gels revealed that the crude protein content on dry and wet basis of the experimental eggs were similar $(\mathrm{P}>0.05)$ to that of whole egg (Table 1). Therefore, the AAP of the experimental eggs was determined and compared to cooked whole egg and egg beaters (Table 2, 3, Figure 1, 2). The limiting essential amino acids (EAA) found in whole egg were leucine and lysine (Table 2). The USDA reported values (dry basis) of 4.05 $\mathrm{g} / 100 \mathrm{~g}$ and $3.40 \mathrm{~g} / 100 \mathrm{~g}$ for leucine and lysine, respectively, which are similar to the whole egg

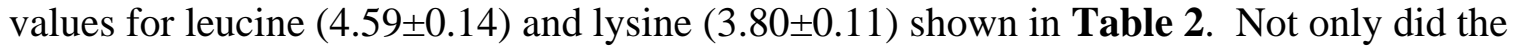
experimental eggs have similar values for leucine and lysine when compared to whole egg, but they also had comparable $(\mathrm{P}>0.05)$ values for histidine, isoleucine, threonine, and tryptophan. In addition, the experimental eggs had higher $(\mathrm{P}<0.05)$ values for methionine, phenylalanine, and valine content compared to whole egg. This is largely due to the fact that the experimental eggs were comprised of more egg white to compensate for the protein that was lost from removal of the yolk. Although the yolk contains some protein ( $\approx 34 \mathrm{~g} / 100 \mathrm{~g}$ dry weight), egg white has about twice the amount of each individual AA when compared to egg yolk (USDA, 2009b). Furthermore, the egg beaters, which is completely composed of egg white, had the highest 
$(\mathrm{P}<0.05)$ amount of all EAA (dry basis) when compared to whole egg and the experimental eggs

(Figure 1). However, it is important to note that this difference is because the AA data is reported on dry weight basis; yet the egg beaters had considerably higher $(\mathrm{P}<0.05)$ moisture content on wet (or as-is) weight basis than whole egg and experimental eggs (Table 1). As mentioned in the previous section ("Proximate analysis of cooked egg gels") for crude protein and total fat, if the AA data had been calculated on wet weight basis, the egg beaters would have actually had lower AA contents than whole egg and experimental eggs. However, despite the statistical differences between EAA levels among treatment groups, it is also important to note that the ratio of total EAA to total AA was similar ( $\mathrm{P}>0.05$ ) for all treatment groups; thus, all eggs had comparable percentages of EAA overall. Moreover, the experimental eggs, with the exception of histidine, exceeded the daily recommended EAA values (mg/g protein) for adults, as established by the Food and Agriculture Organization of the United Nations, the World Health Organization, and the United Nations University (Table 2).

The experimental eggs also had similar $(\mathrm{P}>0.05)$ values for the non-EAA: aspartic acid, glycine, proline, serine, and tyrosine when compared to whole egg values; while higher $(\mathrm{P}<0.05)$ values (than whole egg) for alanine and glutamic acid (Table 3). The higher values for alanine and glutamic acid in the experimental eggs can largely be attributed to the protein content being derived entirely from egg white. Glutamic acid is the most abundant AA found in whole egg, with as much as $10.77 \mathrm{~g} / 100 \mathrm{~g}$ found in the white portion (USDA, 2009b). Furthermore, the USDA reported $6.19 \mathrm{~g} / 100 \mathrm{~g}$ for glutamic acid in whole egg, which is similar to the value for glutamic acid (6.04) shown in Table 3. However, egg beaters with a value of $46.97 \mathrm{~g} / 100 \mathrm{~g}$ (dry basis) contained almost twice the amount of non-EAA when compared to the values of flax egg 
(28.47), menhaden egg (27.88), DHAS egg (28.13), DHASCO egg (28.30), krill egg (28.24), and whole egg (26.96) as shown in Figure 2.

\section{Mineral profile analysis.}

The MP (Ca, P, Mg, and Fe) of whole egg, egg beaters, and the experimental eggs were compared in Figure 3. Calcium, phosphorus, magnesium, and iron were the minerals chosen for analysis because they are the most abundant minerals found in whole eggs. When Ca, P, and Fe content were compared, whole egg had higher $(\mathrm{P}<0.05)$ values than egg beaters or experimental eggs. This is because the majority of these minerals are contained within the yolk portion of whole egg that the egg beaters and experimental eggs lack (Watkins, 1995). The USDA reported values of 284, 920, and $5.42 \mathrm{mg} / 100 \mathrm{~g}$ for Ca, P, and Fe, contained in egg yolk, respectively; compared to much lower values of 62,111 , and $0.15 \mathrm{mg} / 100 \mathrm{~g}$ for $\mathrm{Ca}, \mathrm{P}$, and Fe contained in egg white (dry basis). Thus, egg yolk contains almost all of the Ca, P, and Fe present in the whole egg, except for that in the shell. However, in the case of Fe, nearly all of the Fe in the yolk is bound to the phosphoprotein, phosvitin, which inhibits its release through normal digestion (Greengard, Sentenac, \& Mendelsohn, 1964). In vivo studies by Ishikawa and co-workers (2007) investigated the effects of egg yolk protein and egg yolk phosvitin on the absorption of Ca, Mg, and Fe. They fed rats purified diets containing casein, soy protein, or egg yolk protein for 14 days. These authors found that the absorption of Ca, Mg, and Fe was lower in the rats fed the yolk protein-based diet than those fed the casein and soy protein-based diets indicating that the intake of egg yolk protein decreases not only Fe absorption but also Ca and Mg absorption. Furthermore, when Mg content was compared (Figure 3B), the experimental eggs (with the exception of DHASCO algae eggs) had values comparable to those of egg beaters (42.3 mg/100 g) and higher $(\mathrm{P}<0.05)$ than whole egg values $(36.2 \mathrm{mg} / 100 \mathrm{~g})$. This result is due 
to the fact that egg whites have a much higher $\mathrm{Mg}$ content at $\approx 88 \mathrm{mg} / 100 \mathrm{~g}$ when compared to $\approx 13 \mathrm{mg} / 100 \mathrm{~g}$ for egg yolk (USDA, 2009b).

\section{Cholesterol Profile.}

Figure 4 reveals the cholesterol profile of the experimental eggs compared to the cholesterol content of whole egg $(\mathrm{P}<0.05)$. Although, the values are statistically different, whole egg contained a significantly higher amount of cholesterol compared to the experimental eggs. Krill and menhaden oils are derived from animal fats, thus a small amount of cholesterol in the krill and menhaden eggs is not unexpected. However, flaxseed and algae oils are plant-derived fats and should not contain cholesterol. A possible explanation for the trace amounts of cholesterol present in the flax and algae eggs can be attributed to the incidental incorporation of yolk into the experimental batters during the egg separation process.

\section{Fatty acid profile analysis}

Proximate analysis of the cooked egg gels (Table 1) showed that the experimental eggs had similar values for crude fat (dry basis) when compared to whole egg $(\mathrm{P}<0.05)$. However, FAP analysis revealed significant differences in the percentage of specific PUFAs among treatment groups (Figure 5). Eicosapentaenoic acid (EPA, 20:5n-3), docosahexaenoic acid (DHA, 22:6n-3), and linolenic (ALA, 18:3n-3) were the main n-3 PUFAs, whereas linoleic acid (LA, 18:2n-6) and arachidonic acid (AA, 20:4n-6) were the main n-6 PUFAs that were analyzed. In general, the experimental eggs contained significantly higher amounts (28-47\%) of n-3 PUFAs than whole egg (6\%) and significantly lower amounts of n-6 PUFAs (3-6\%), with the exception of flax eggs, than whole egg (16\%). Furthermore, whole egg also contained significantly higher levels of saturated fat than the experimental eggs, which was expected. ALA is the major fatty acid found in flaxseed oil, thus the flax eggs contained the highest amount 
(42.2\%) of ALA compared to the other experimental eggs (menhaden, 1.61\%; DHAS, 1.41\%, DHASCO, 4.07\%; krill,1.44\%) as well as whole egg ( $<1.0 \%)$. Previous studies ( Ferrier et al., 1995; Arantes da Silva et al., 2008) that have either utilized or produced omega-3-enriched poultry eggs by adding flaxseed to the animal feed, have reported ALA values no greater than

11\%. Furthermore, menhaden (11.3\%) and krill (24.7\%) eggs had the largest percentage of EPA when compared to the other groups $(<1 \%)$, which is consistent with the fact that fish oils are richest known sources of EPA. In addition, krill eggs had the highest percentage of AA. AA is a major constituent of the phospholipids of cell membranes and krill oil contains relatively high levels of phospholipids; values as high as 54-58\% have been reported (Bottino, 1975). DHA, the main PUFA found in marine algae, was seen at highest levels in algae eggs, DHAS and DHASCO, in comparison to other experimental eggs and whole egg, with values of 35.9\% and $37.8 \%$, respectively. Furthermore, the ratio of n-6/n-3 PUFAs was twice as high in whole egg in comparison to experimental eggs (Table 4).

\section{Lipid Oxidation}

Figure 6 shows the results of TBARS analysis of the experimental cooked egg gels as compared to cooked whole egg. Krill eggs were the most susceptible to lipid oxidation (compared to other treatment groups), which can be explained by the FAP of krill eggs (Figure 5). Krill eggs contained the highest level of n-3 PUFAs, whose long, unsaturated fatty acid chains are more prone to oxidation than other fatty acids. Algae eggs, which contained similar levels of ALA and EPA when compared to whole egg, also had comparable oxidation capacity to that of whole egg. Furthermore, because menhaden oil, like krill, is a fish oil, it was hypothesized that menhaden eggs would have similar oxidation susceptibility to krill eggs. However, FAP analysis revealed that menhaden eggs contained significantly lower levels of 
EPA than krill eggs, as well as lower levels of total n-3 PUFAs than all other experimental eggs, which can be attributed to its comparatively lower oxidation capacity. Antioxidants, such as $\alpha$ tocopherol or ascorbic acid are often added to omega-3-enriched food products to prevent or stabilize lipid oxidation. Franchini et al. (2002) studied the effects of the addition of mega doses of vitamins $\mathrm{E}$ and $\mathrm{C}$ to hen feed. TBARS analysis revealed no significant differences in control groups as compared to supplemental groups, thus these authors concluded that vitamin supplementation had no effect on egg yolk lipid oxidation. Further investigation is needed to determine whether the addition of such an antioxidant, would aid in lipid stability or oxidation prevention in the present study.

\section{Color properties}

Table 5 displays the tristimulus color values ( $\mathrm{L}^{*} \mathrm{a} \mathrm{b}^{*}$ ) of the cooked egg gels. $\mathrm{L} *$ is a relative measurement between the light reflected and absorbed by the samples where each color can be considered equivalent to a member of the gray scale ranging from 0 to 100 corresponding to a gradual scale from black to white, respectively. When menhaden, DHAS, and DHASCO oils were used in the experimental eggs, the $L^{*}$ values were $88.0 \pm 0.3,87.7 \pm 0.2$, and $86.6 \pm 0.8$, respectively. These $L^{*}$ values were similar $(\mathrm{P}>0.05)$ to that of whole egg (87.2 \pm 0.9$)$. Egg beaters were the lightest in color (because they lack yolk); and thus, had the highest $(\mathrm{P}<0.05) \mathrm{L}^{*}$ value (92.7 \pm 0.8$)$. In contrast, the experimental eggs that contained krill oil were visibly darker in color compared to all other samples and had the lowest $(\mathrm{P}<0.05) \mathrm{L}^{*}$ value $(73.1 \pm 0.6)$.

The other two tristimulus color values, $\mathrm{a}^{*}$ and $\mathrm{b}^{*}$ are coordinates in which $\mathrm{a}^{*}$ has positive or negative values for reddish or greenish hues, respectively; whereas, $b^{*}$ has positive or negative values for yellowish or bluish hues, respectively. In terms of consumer acceptability of 
whole egg products, typically the yellow coordinate (i.e., positive b*) is considered the most important hue from the color spectrum. Therefore, positive $b^{*}$ is likely the most important color value for egg products. Whole egg and egg beaters had negative a* values of $-4.3 \pm 0.2$ and 3.1 \pm 0.1 , respectively; while experimental eggs had positive $a^{*}$ (0.9-3.7 except krill), with the experimental eggs that contained krill oil having the highest $(\mathrm{P}<0.05) \mathrm{a}^{*}$ value $(37.5 \pm 1.1)$. The experimental eggs containing krill oil had the most prominent red hue. However, it needs to be emphasized that although whole egg and egg beaters had significantly different a* from experimental eggs, the numerical differences were relatively small except for experimental eggs containing krill oil. The reddish color of the krill oil is the result of the bright red pigment asthaxanthin, an antioxidant that is produced by algae that krill feed on (Bustos, Romo, Yanez, Diaz, \& Romo, 2003).

The experimental eggs had more $(\mathrm{P}<0.05)$ positive $\mathrm{b}^{*}$ values than whole egg or egg beaters indicating more yellow hues in their color. Experimental eggs containing algae (DHAS and DHASCO) and krill oils had the most $(\mathrm{P}<0.05)$ positive $\mathrm{b}^{*}$ values $(49.0 \pm 1.2,52.0 \pm 2.0$, and 51.0 \pm 2.2 , respectively), which again are the direct contribution of antioxidant pigmentation. These antioxidants were present in the oils added during formulation of the experimental batters. Although the same concentration of annatto pigment was used during formulation of the experimental batters, the original color of the added oils likely contributed to the differences in $\mathrm{b}^{*}$ values. Flaxseed and menhaden oils had less intense yellow color; and therefore, the $\mathrm{b}^{*}$ values for experimental eggs containing these oils were lower $(\mathrm{P}<0.05)$ than for eggs containing algae and krill oils, yet higher $(\mathrm{P}<0.05)$ than $\mathrm{b}^{*}$ for whole egg and egg beaters. Herber-McNeill and Van Elswyk (1998) investigated addition of marine algae to chicken feed. They reported similar $\mathrm{a}^{*}(2.7 \pm 0.4)$ and $\mathrm{b}^{*}(47.2 \pm 0.4)$ and found that these values enhanced consumer 
acceptability of eggs. Therefore, more yellow hue in the experimental eggs reported in the present study would likely be acceptable to consumers. However, sensory studies including consumer acceptability are needed to determine this factor.

\section{Texture analysis}

Kramer shear force was similar ( $\mathrm{P}>0.05)$ for all samples tested except experimental eggs containing flaxseed and menhaden oil had firmer $(\mathrm{P}<0.05)$ texture than egg beaters (Figure 7). This result was expected since krill oil contains the highest concentration of phospholipids compared to the other $\omega$-3-rich oils used in this experiment. Furthermore, the addition of soybean lecithin to the experimental eggs containing DHASCO contributed to emulsification of the added DHASCO oil, rendering shear force comparable ( $\mathrm{P}>0.05)$ to that of whole egg (Figure 7). Emulsification results in stabilization of the product, which in turn requires more shear force to fracture a sample. This is also confirmed by the torsion shear stress and TPA hardness

presented in Figures 8 and 9, respectively; where the values of both whole egg and experimental eggs were higher $(\mathrm{P}<0.05)$ than those of egg beaters. Moreover, there was no $(\mathrm{P}>0.05)$ difference in shear strain among the samples tested (Figure 8). Shear strain is a measure of gel cohesiveness; and thus, the shear strain for all samples, ranging from 0.93-1.19, confirmed the TPA cohesiveness values, ranging from $0.61-0.65$ (with the exception of the egg beaters at 0.27 ) (Table 2). The numerical difference between shear strain of egg beaters measured with torsion test and TPA can be explained by the different test (TPA - empirical test, torsion - fundamental test) and cooking methods (TPA - microwave, torsion test - water bath).

Texture profile analysis (TPA) revealed no differences $(\mathrm{P}<0.05)$ in the six texture parameters (hardness, springiness, cohesiveness, gumminess, chewiness, and resilience) of the experimental eggs compared to whole egg (Figure 9, Table 6). Similar TPA values for whole 
egg texture have been reported (Franchini, Sirri, Tallarico, Minelli, Iaffaldano, \& Meluzzi, 2002). Thus, the substitution of yolk with $\omega-3$ PUFA-rich oils does not alter texture of cooked egg as determined with TPA. In 2004, Hoz et al. investigated the enhancement of sausages with $\omega-3$ PUFA-rich oils and found no differences $(\mathrm{P}<0.05)$ in the TPA parameters when compared to control values. The TPA data shown in the present study confirms similar trend. The varying phospholipid concentrations of the $\omega$-3 PUFA-rich oils facilitated stabilization of the meat emulsion system in the sausages (Hoz et al, 2004). Similar stabilization likely occurred due to yolk phospholipids and phospolipids (including soybean lecithin) of the alternative oils (krill, flaxseed, algae, and menhaden oils) that emulsified fat in whole egg and experimental eggs, respectively; thus, resulting in similar textural properties in the present study. A similar trend was also suggested for meat products fortified with $\omega$-3 PUFA (Lee, Faustman, Djordjevic, Faraji, \& Decker, 2005). The TPA values of egg beaters showed consistently much poorer $(\mathrm{P}<0.05)$ textural properties for all of the six TPA parameters when compared to whole egg and experimental eggs. The poorer texture of egg beaters can be attributed to high moisture content (87.5 g/100) in addition to the low protein (9.9 g/100g, wet basis) and lipid (0.3 g/100g, wet basis) content (Table 1). Similar values for springiness (0.88) and cohesiveness (0.23) have been reported for cooked egg whites (Min, Nam, Lee, Ko, Trampel, \& Ahn, 2005). 


\section{Conclusions}

Substitution of the saturated fat and cholesterol from egg yolk with various sources of omega-3 fatty acids resulted in the development of a nutritionally-enhanced egg product. The objectives to match the enhanced product to whole egg on the basis of proximate composition and texture were met. The experimental eggs had values comparable to those of whole egg for protein, total lipid, and moisture. Nutritionally, the experimental eggs contained the same ratio of EAA/AA as in whole egg, and even exceeded the RDA for EAA (mg/g protein) for adults. Mineral profile analysis showed that the experimental eggs contained lesser amounts of $\mathrm{Ca}, \mathrm{P}$, and Fe than whole egg, explained by lack of yolk, and a higher amount of Mg. Cholesterol profile showed that the cholesterol content of the experimental eggs was significantly lower than that of whole egg $(\mathrm{P}<0.05)$. Fatty acid profile analysis showed that not only did the experimental eggs have a significantly higher omega-3 content than whole egg, but also have a much lower n6/n-3 ratio as compared to whole egg. TBARS analysis showed that the rate of lipid oxidation for the experimental eggs is at least the same as whole egg, with the exception of krill eggs, or less. Finally, texture analysis showed that there were no differences between the experimental eggs and whole egg on six different texture parameters, as well as tristimulus color analysis, with the exception of krill eggs. Although, the results of this study point towards the potential for a novel, marketable functional food product, additional sensory testing is necessary. 


\section{References}

Arantes da Silva, W. A., Elias, A. H. N., Aricetti, J. A., Sakamoto, M. I., Murakami, A. E., Gomes, S. T. M.,Visentainer, J. V., Souza, N. E., \& Matsushita, M. (2008). Quail egg yolk (Coturnix coturnix japonica) enriched with omega-3 fatty acids. LWT-Food Science and Technology, 42, 660-663.

Arterburn, L. M., Oken, H. A., Hall, E. B., Hamersley, J., Kuratko, C. N., \& Hoffman, J. P. (2008). Algal-oil capsules and cooked salmon: nutrionally equivalent sources of docosahexaenoic acid. Journal of the American Dietetic Association, 108, 1204-1209.

Association of Official Analytical Chemists. (1995). Official Methods of Analysis. 16th ed., Washington, DC: Association of Official Analytical Chemists.

Bodwell, C. E.; Satterlee, L. D.; Hackler, L. R. (1980). Protein digestibility of the same protein preparations by human and rat assays and by in vitro enzymatic digestion assays.

American Journal of Clinical Nutrition, 33, 677-686.

Bottino, N. R. (1975). Lipid composition of two species of Antarctic krill: Euphausia superba and E. crystallorophias. Comparative Biochemistry and Physiology B, 50, 479-484.

Bustos, R., Romo, L., Yanez, K., Diaz, G., \& Romo, C. (2003). Oxidative stability of carotenoid pigments and polyunsaturated fatty acids in microparticulate diets containing krill oil for nutrition of marine fish larvae. Journal of Food Engineering, 56, 289-293.

Chen, Y. C., \& Jaczynski, J. (2007a). Gelation of protein recovered from Antarctic krill (Euphausia superba) by isoelectric solublization/precipitation as affected by function additives. Journal of Agricultural and Food Chemistry, 55, 1814-1822.

Chen, Y. C., \& Jaczynski, J. (2007b). Protein recovery from rainbow trout (Oncorhynchus mykiss) processing by-products via isoelectric solubilization / precipitation and its gelation properties as affected by functional additives. Journal of Agricultural and Food Chemistry, 55, 9079-9088.

Cheret, R., Chapleau, N., Delbarre-Ladrat, C., Verrez-Bagnis, V., \& Lamballerie, M. D. (2005). Effects of high pressure on texture and microstructure of sea bass (Dicentrarchus labrax L.) fillets. Journal of Food Science, 70, E477-483.

Ferrier, L. K., Caston, L. J., Leeson, S., Squires, J., Weaver, B. J., \& Holub, B. J. (1995). $\alpha-$ Linolenic acid-and docosahexaenoic acid-enriched eggs from hens fed flaxseed: influence on blood lipids and platelet phospholipid fatty acids in humans. The American Journal of Clinical Nutrition, 62, 81-86. 
Franchini, A., Sirri, F., Tallarico, N., Minelli, G., Iaffaldano, \& N., Meluzzi, A. (2002). Oxidative stability and sensory and functional properties of eggs from laying hens fed supranutritional doses of vitamins E and C. Poultry Science, 81, 1744-1750.

Freud, R. J., \& Wilson, W.J. (1997). Design of experiments (p 464). San Diego (CA): Academic Press.

Greengard, O.; Sentenac, A.; Mendelsohn, N. (1964). Phosvitin, the iron carrier of egg yolk. Biochem. Biophys. Acta., 90, 406-407.

Herber-McNeill, S. M., \& Van Elswyk, M. E. (1998). Dietary marine algae maintains egg consumer acceptability while enhancing yolk color. Poultry Science, 77, 493-496.

Herron, K. L., \& Fernandez, M. L. (2004). Are the current dietary guidelines regarding egg consumption appropriate? The Journal of Nutrition, 134, 187-190.

Howell, W. H., McNamara, D. J., Tosca, M. A., Smith, B. T., \& Gaines, J. A. (1997). Plasma lipid and lipoprotein responses to dietary fat and cholesterol: a meta-analysis. American Journal of Clinical Nutrition, 65, 1747-1764.

Hoz, L., D’Arrigo, M., Cambero, I., \& Ordóñez, J. A. (2004). Development of an n-3 fatty acid and $\alpha$-tocopherol enriched dry fermented sausage. Meat Science, 67, 485-495.

Hu, F. B., Stampfer, M. J., Manson, J. E., Ascherio, A., Colditz, G. A., Speizer, F. E., Hennekens, C. H., \& Willett, W. C. (1999). Dietary saturated fats and their food sources in relation to the risk of coronary heart disease in women. American Journal of Clinical Nutrition, 70(6), 1001-1008.

Ihaka, R., \& Gentleman, R. (1996). R: A language for data analysis and graphics. Journal of Computational and Graphical Statistics, 5, 299-314.

Ishikawa, S. I.; Tamaki, S.; Arihara, K.; Itoh, M. (2007). Egg yolk protein and egg yolk phosvitin inhibit calcium, magnesium, and iron absorptions in rats. Journal of Food Science, 72 (6) 412-419.

Jaczynski, J., \& Park, J. W. (2004). Physicochemical changes in Alaska Pollock surimi and surimi gel as affected by electron beam. Journal of Food Science, 69, 53-57.

Juturu, V. (2008). Omega-3 fatty acids and the cardiometabolic syndrome. Journal of Cardiometabolic Syndrome, 3(4), 244-253.

Kim, B. Y., Park, J. W., \& Yoon, W. B. (2005). Rheology and texture properties of surimi gels. In J. W. Park, Surimi and Surimi Seafood, $2^{\text {nd }}$ ed. (p 491-582). Boca Raton (FL): Taylor and Francis Group. 
Lee, S., Faustman, C., Djordjevic, D., Faraji, H., \& Decker, E. A. (2005). Effect of antioxidants on stabilization of meat products fortified with n-3 fatty acids. Meat Science, 72(1), 18-24.

Leutzinger, R. L., Baldwin, R. E., \& Cotterill, O. J. (1977). Sensory attributes of commercial egg substitutes. Journal of Food Science, 42(4), 1124-1125.

Min, B. R., Nam, K. C., Lee, E. J., Ko, G. Y., Trampel, D. W., \& Ahn, D. U. (2005). Effect of irradiating shell eggs on quality attributes and functional properties of yolk and white. Poultry Science, 84, 1791-1796.

Oh, S. Y., Ryue, J., Hsieh, C., Bell, D.E. (1991). Eggs enriched in $\omega$-3 fatty acids and alterations in lipid concentrations in plasma and lipoproteins and in blood pressure. American Journal of Clinical Nutrition, 54, 689-695.

Psota, T. L., Gebauer, S. K., \& Kris-Etherton, P. (2006). Dietary omega-3 fatty acid intake and cardiovascular risk. American Journal of Cardiology, 98 (suppl), 3i-18i.

Scheideler, S. E., Froning, G., \& Cuppett, S. (1997). Studies of consumer acceptance of high omega-3 fatty acid-enriched eggs. Journal of Applied Poultry Research, 6, 137-146.

Siró, I., Kápolna, E., Kápolna, B., \& Lugasi, A. (2008). Functional food. Production, marketing and consumer acceptance - a review. Appetite, 51, 456-467.

Taskaya, L., Chen, Y. C., \& Jaczynski, J. (2009a). Color improvement by titanium dioxide and its effect on gelation and texture of proteins recovered from whole fish using isoelectric solubilization / precipitation. LWT - Food Science and Technology. Revision submitted.

Taskaya, L., Chen, Y. C., \& Jaczynski, J. (2009b). Functional properties of proteins recovered from whole gutted silver carp (Hypophthalmichthys molitrix) by isoelectric solubilization / precipitation. LWT - Food Science and Technology 42(6), 1082-1089.

Taskaya, L., Chen, Y. C., Beamer, S., \& Jaczynski J. (2009c). Texture and colour properties of proteins recovered from whole gutted silver carp (Hypophthalmichthys molitrix) using isoelectric solubilisation / precipitation. Journal of the Science of Food and Agriculture 89(2), 349-358.

USDA. 2009a. Agricultural Research Service. Per Capita Egg Consumption. Assessed on January 26, 2009. http://www.usda.gov/wps/portal/usdahome

USDA. 2009b. Nutrient Data Laboratory. Assessed on May 25, 2009. http://www.ars.usda.gov/main/site_main.htm?modecode=12-35-45-00

Watkins, B. A. The nutritive value of the egg. Food Products Press, Binghamton (NY), 1995.

Weggemans, R. M., Zock, P. L., \& Katan, M. B. (2001). Dietary cholesterol from eggs increases the ratio of total cholesterol to high-density lipoprotein cholesterol in humans: a meta-analysis. American Journal of Clinical Nutrition, 73, 885-891. 
Yu Tc, Sinnhuber RO. 1957. 2-Thiobarbituric acid method for the measurement of rancidity in fishery products. Food Technology, 11:104-108. 


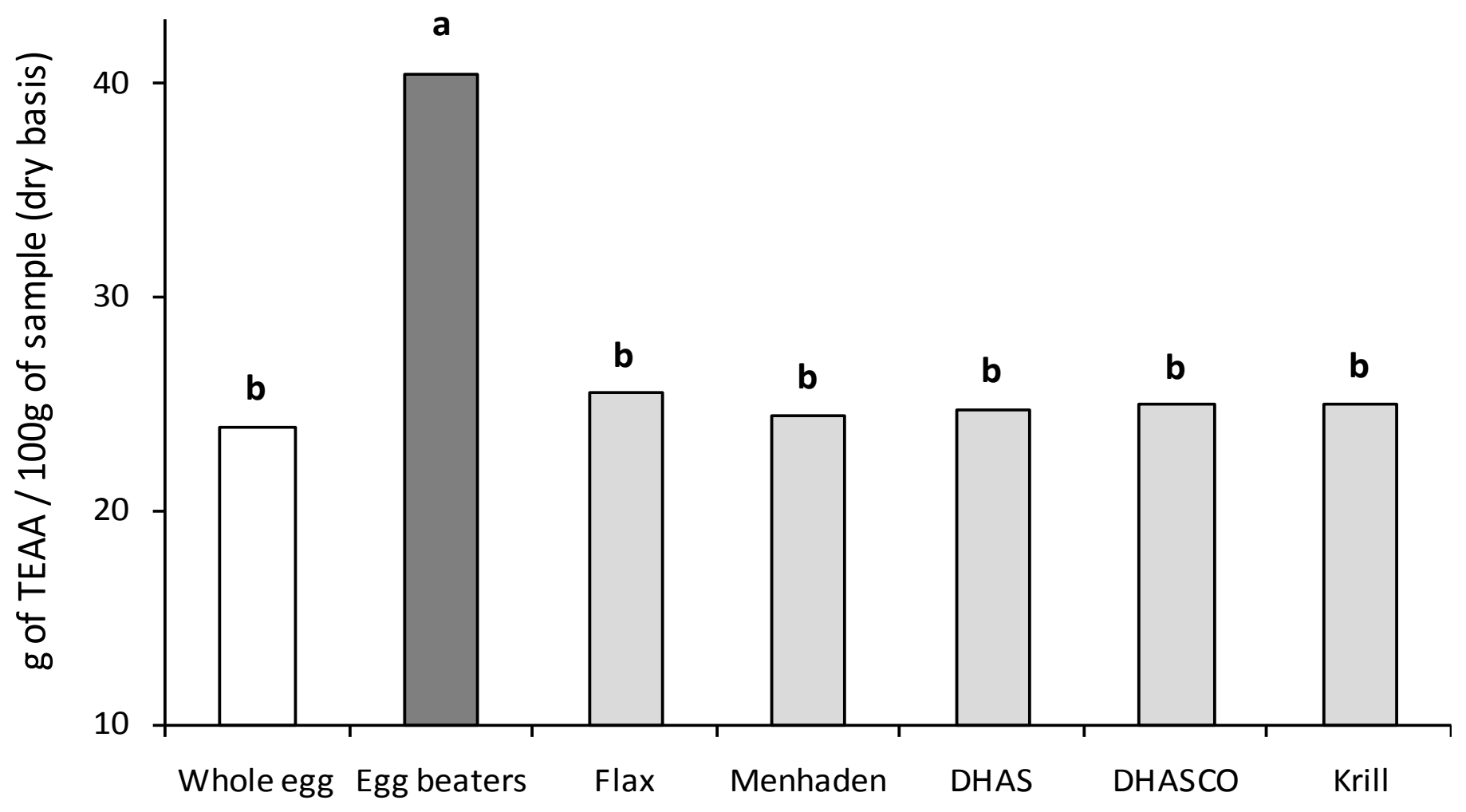

Figure 1. Total essential amino acids (TEAA) content* of cooked whole egg and egg beaters was compared to cooked experimental eggs developed with addition of flaxseed, menhaden, algae (DHAS and DHASCO), and krill oils. * Data are given as mean values \pm standard deviation $(\mathrm{n}=3)$. Different letters on the top of data bars indicate significant differences (Fisher's Least Significant Difference, $\mathrm{P}<0.05$ ) between mean values. 


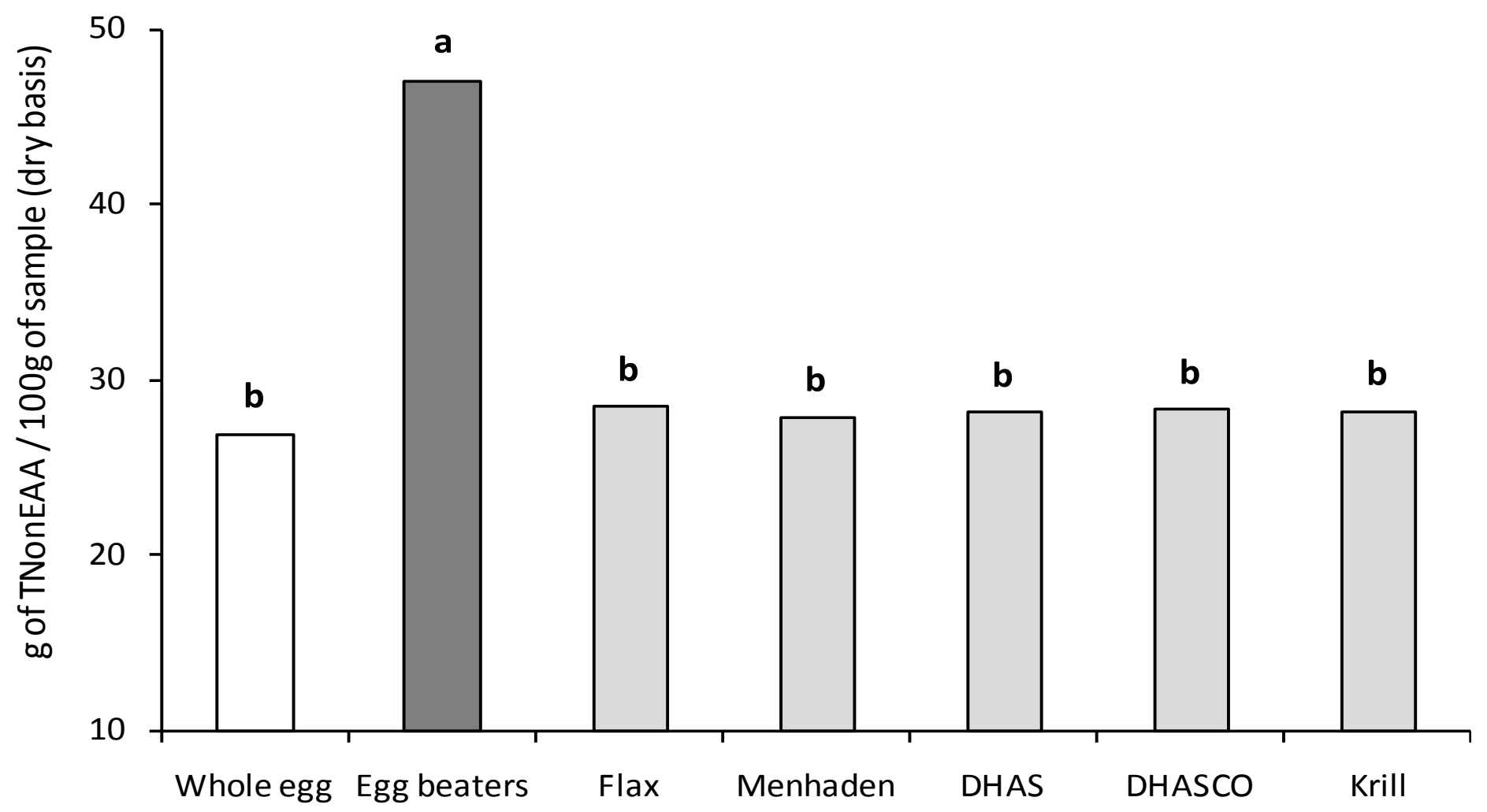

Figure 2. Total non-essential amino acids (TNonEAA) content* of cooked whole egg and egg beaters was compared to cooked experimental eggs developed with addition of flaxseed, menhaden, algae (DHAS and DHASCO), and krill oils.

* Data are given as mean values \pm standard deviation $(\mathrm{n}=3)$. Different letters on the top of data bars indicate significant differences (Fisher's Least Significant Difference, $\mathrm{P}<0.05$ ) between mean values 

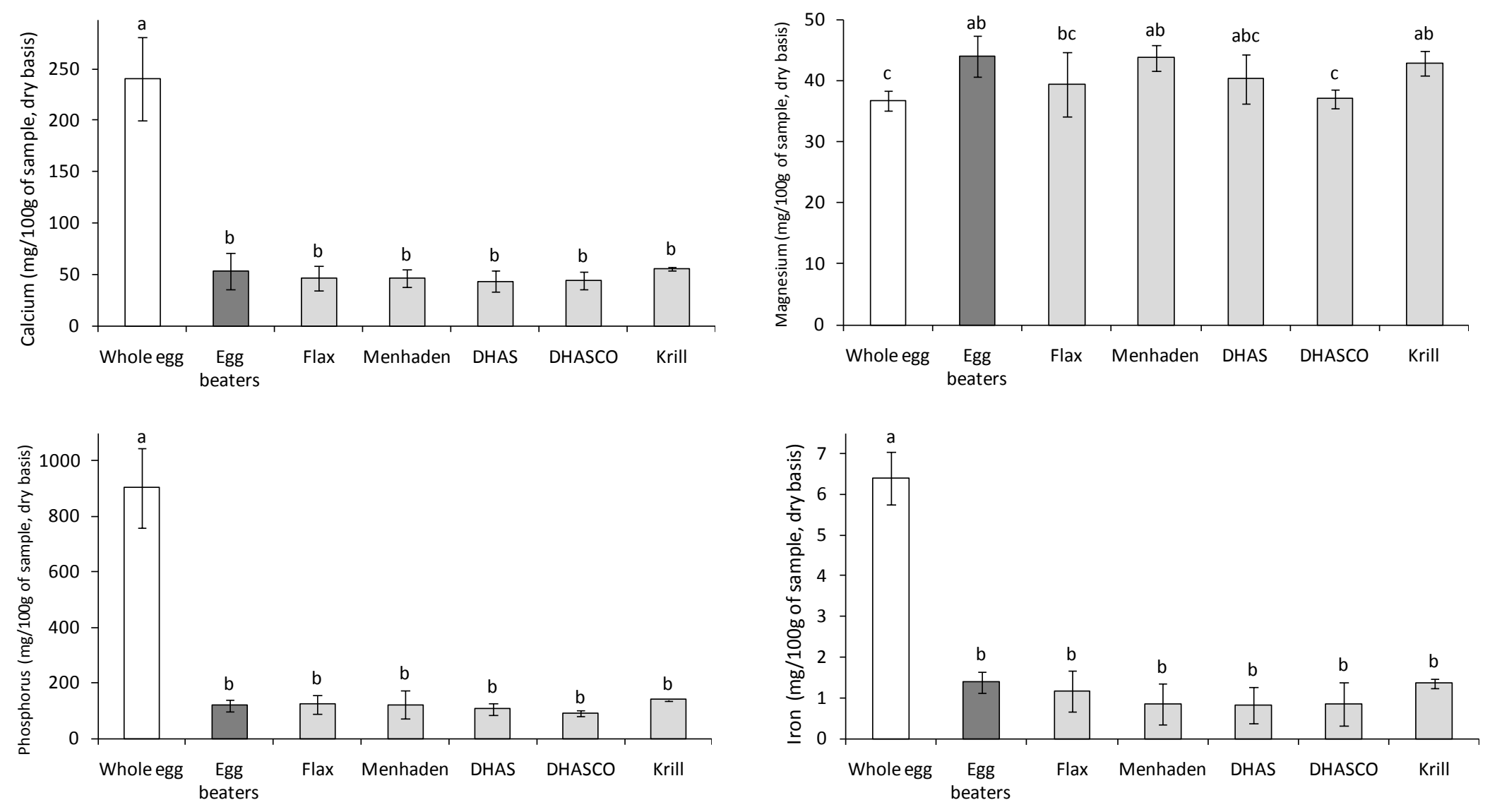

Figure 3. Mineral (Ca, Mg, P, Fe) content* of cooked whole egg and egg beaters was compared to cooked experimental eggs developed with addition of flaxseed, menhaden, algae (DHAS and DHASCO), and krill oils. * Data are given as mean values \pm standard deviation $(\mathrm{n}=3$ ). Different letters on the top of data bars indicate significant differences (Fisher's Least Significant Difference, $\mathrm{P}<0.05)$ between mean values. 


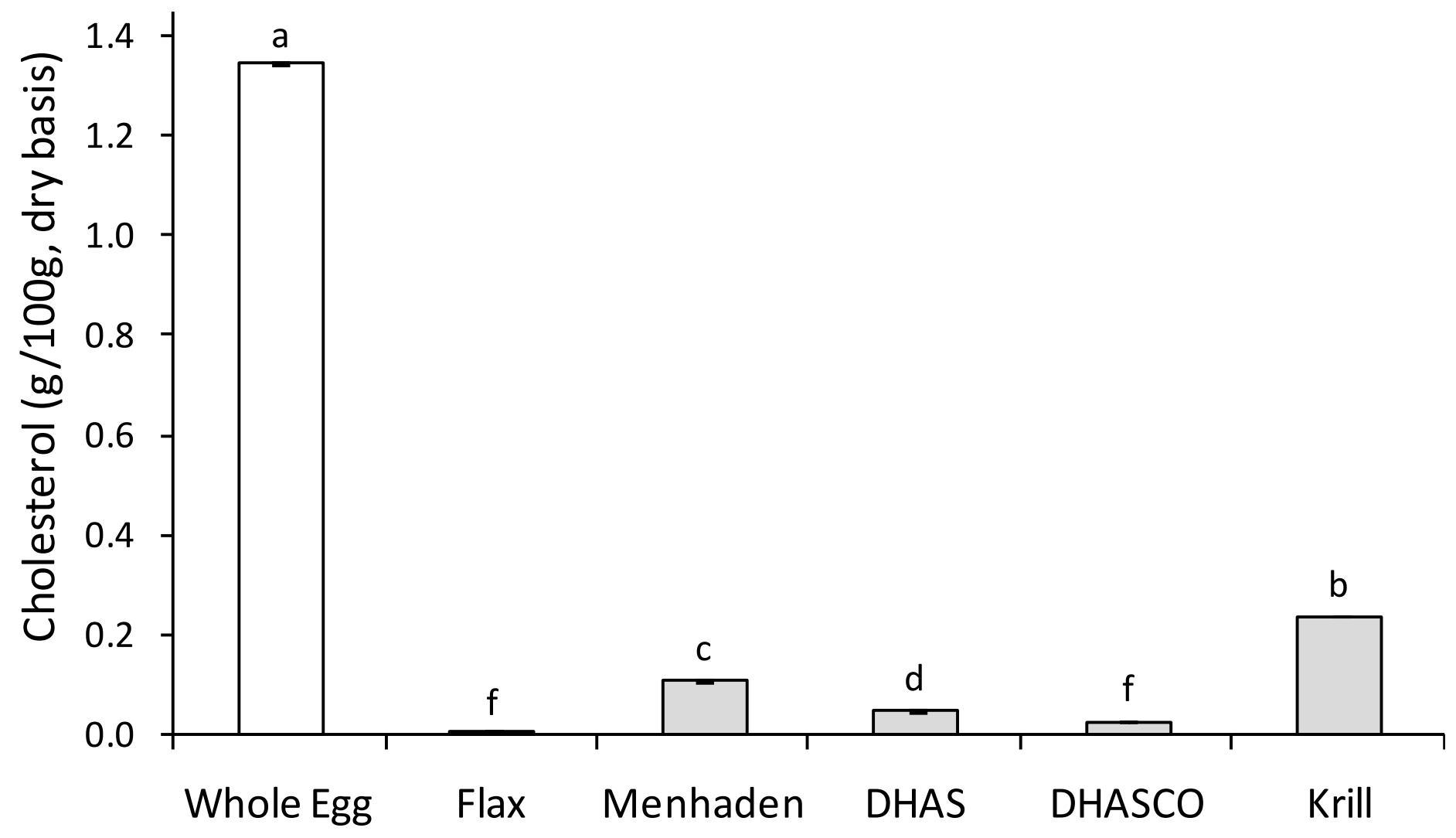

Figure 4. Cholesterol content* of cooked whole egg was compared to cooked experimental eggs developed with addition of flaxseed, menhaden, algae (DHAS and DHASCO), and krill oils. * Data are given as mean values \pm standard deviation $(\mathrm{n}=3)$. Different letters on the top of data bars indicate significant differences (Fisher's Least Significant Difference, $\mathrm{P}<0.05$ ) between mean values. 

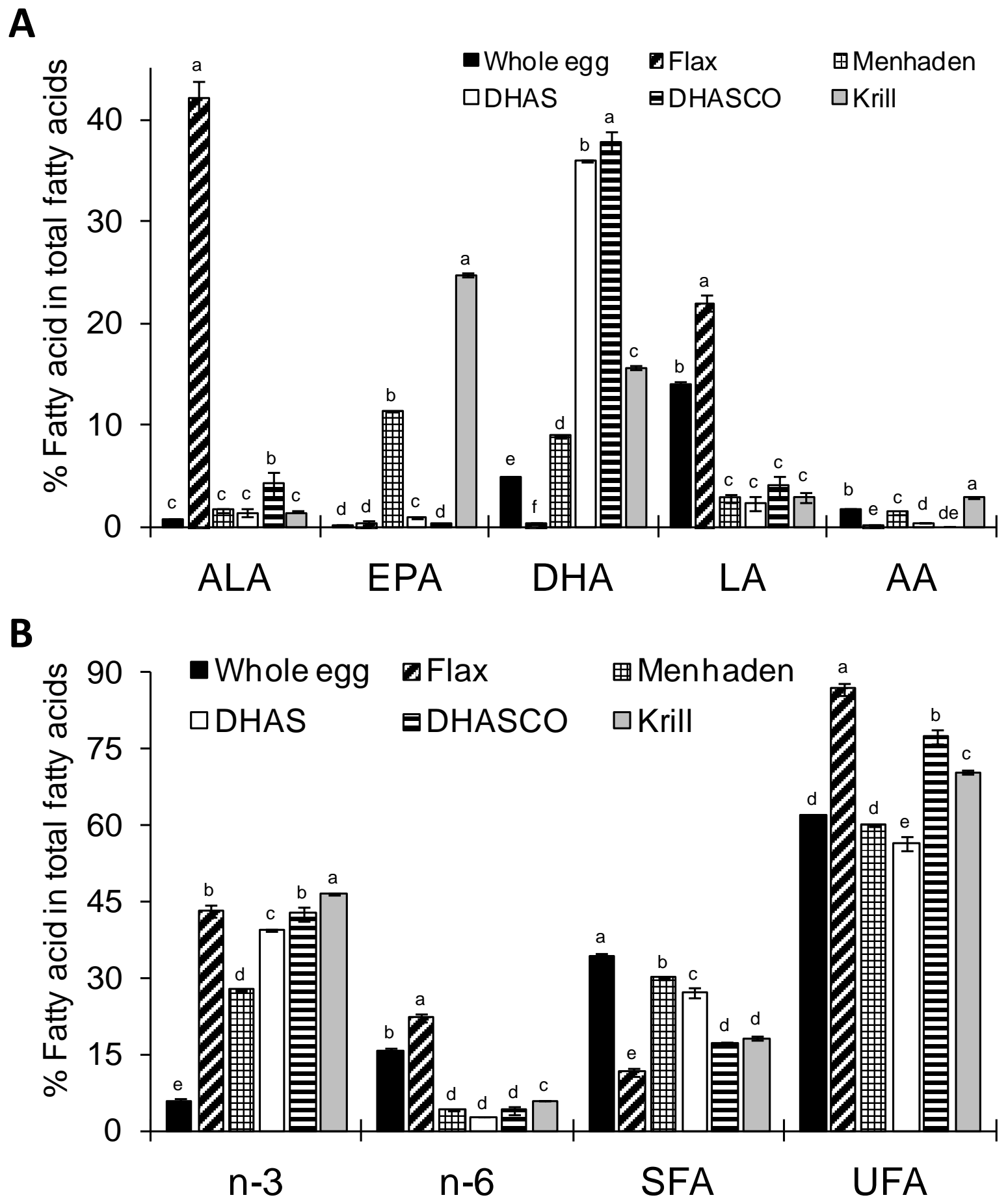

Figure 5. Percentage of specific fatty acid within total fatty acids of cooked whole egg was compared to cooked experimental eggs developed with the addition of flaxseed, menhaden, algae (DHAS and DHASCO), and krill oils. *Data are given as mean values \pm standard deviation $(\mathrm{n}=3)$. Different letters indicate significant differences (Fisher's Least Significant Difference, $\mathrm{P}<0.05$ ) between mean values. 


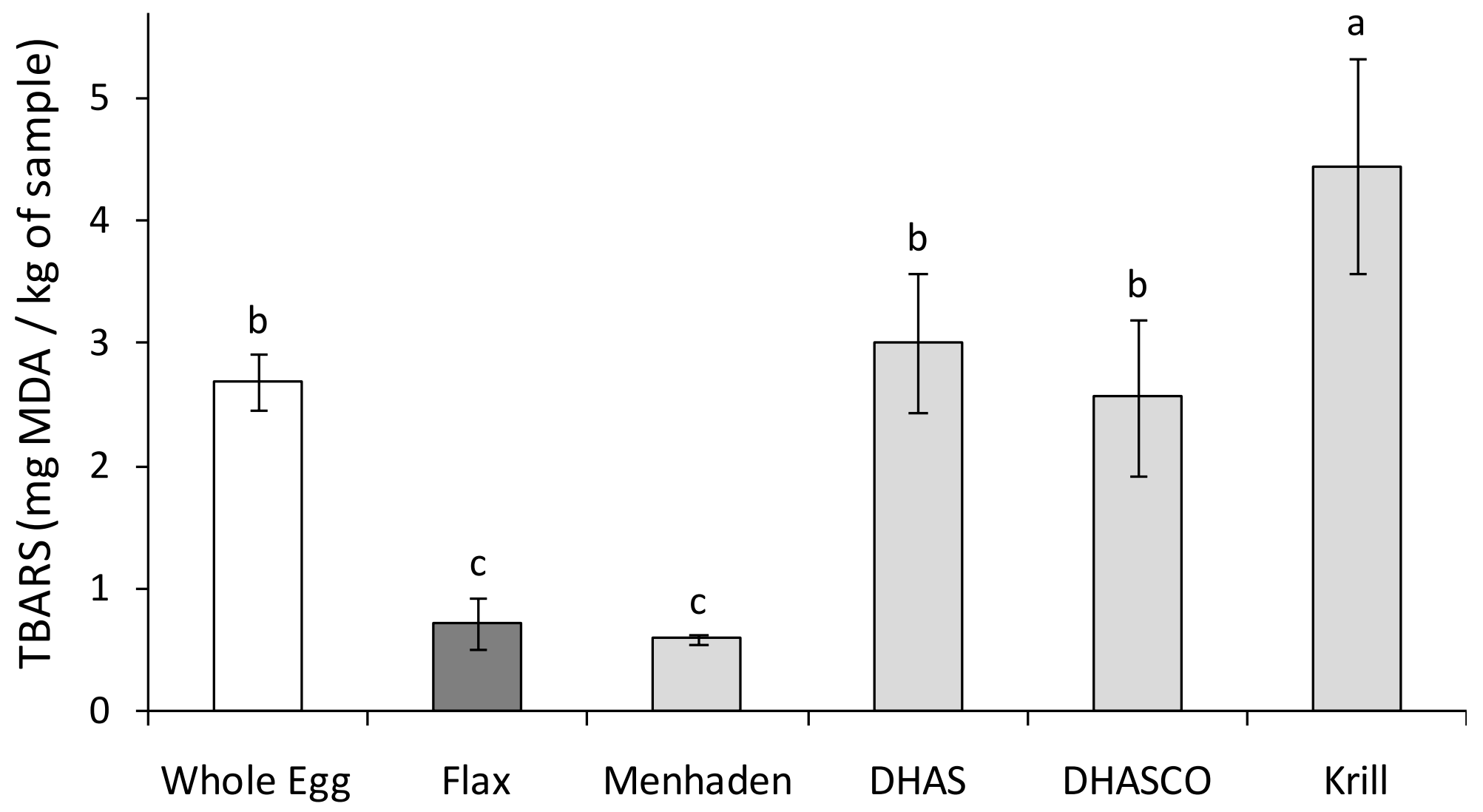

Figure 6. Thiobarbituric acid reactive substances test (TBARS) measured lipid oxidation capacity of cooked whole egg compared to cooked experimental eggs developed with the addition of flaxseed, menhaden, algae (DHAS and DHASCO), and krill oils. Color absorbance was read at 532nm and TBARS values were reported as mg malondialdehyde (MDA) per kilogram of sample.

*Data are given as mean values \pm standard deviation $(n=3)$. Different letters indicate significant differences (Fisher's Least Significant Difference, $\mathrm{P}<0.05$ ) between mean values. 


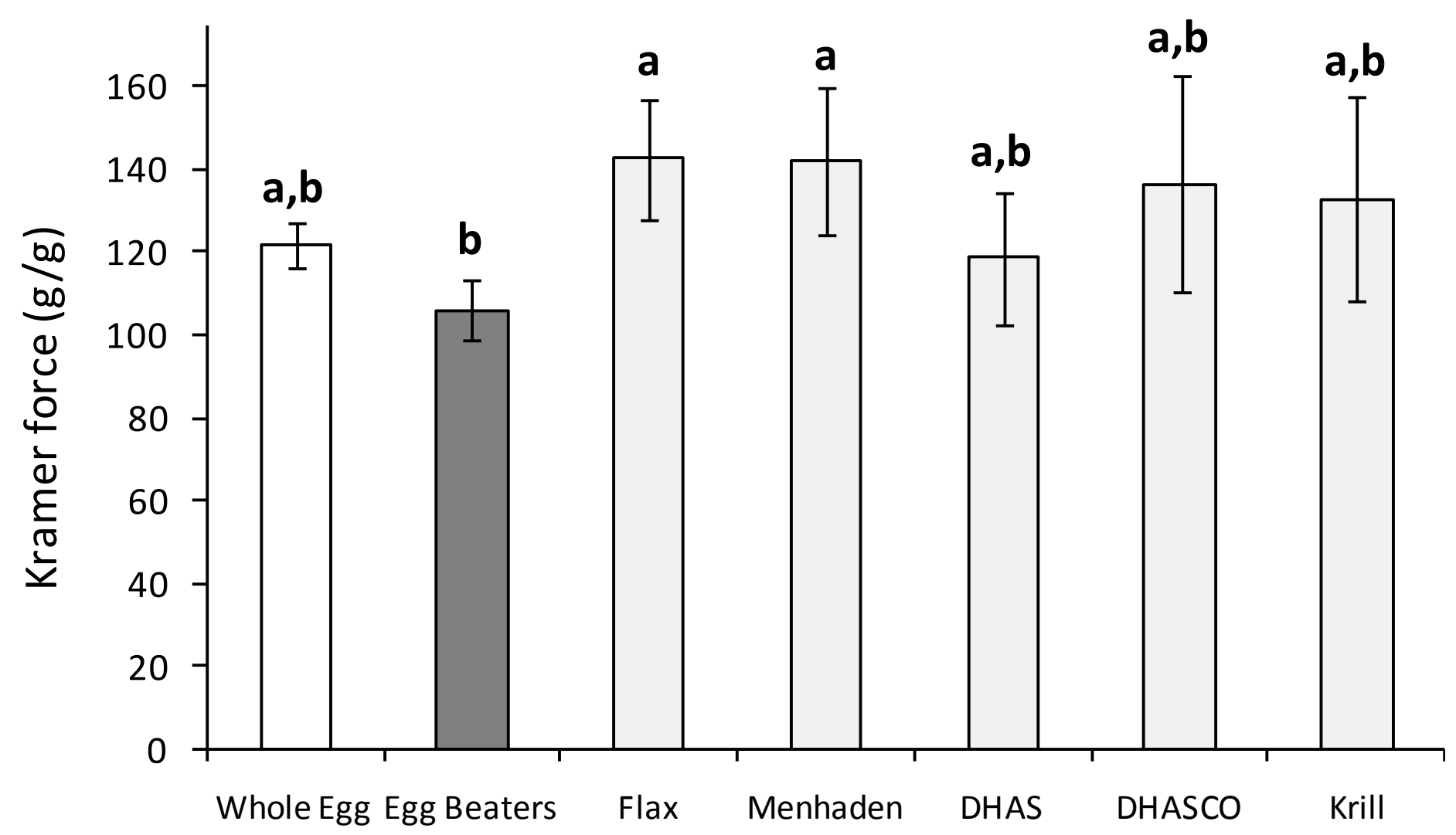

Figure 7. Kramer shear force* of cooked gels. Kramer force of cooked whole egg and egg beaters was compared to cooked experimental eggs developed with addition of flaxseed, menhaden, algae (DHAS and DHASCO), and krill oils. * Data are given as mean values \pm standard deviation $(n=3)$. Different letters on the top of data bars indicate significant differences (Fisher's Least Significant Difference, $\mathrm{P}<0.05)$ between mean values. 


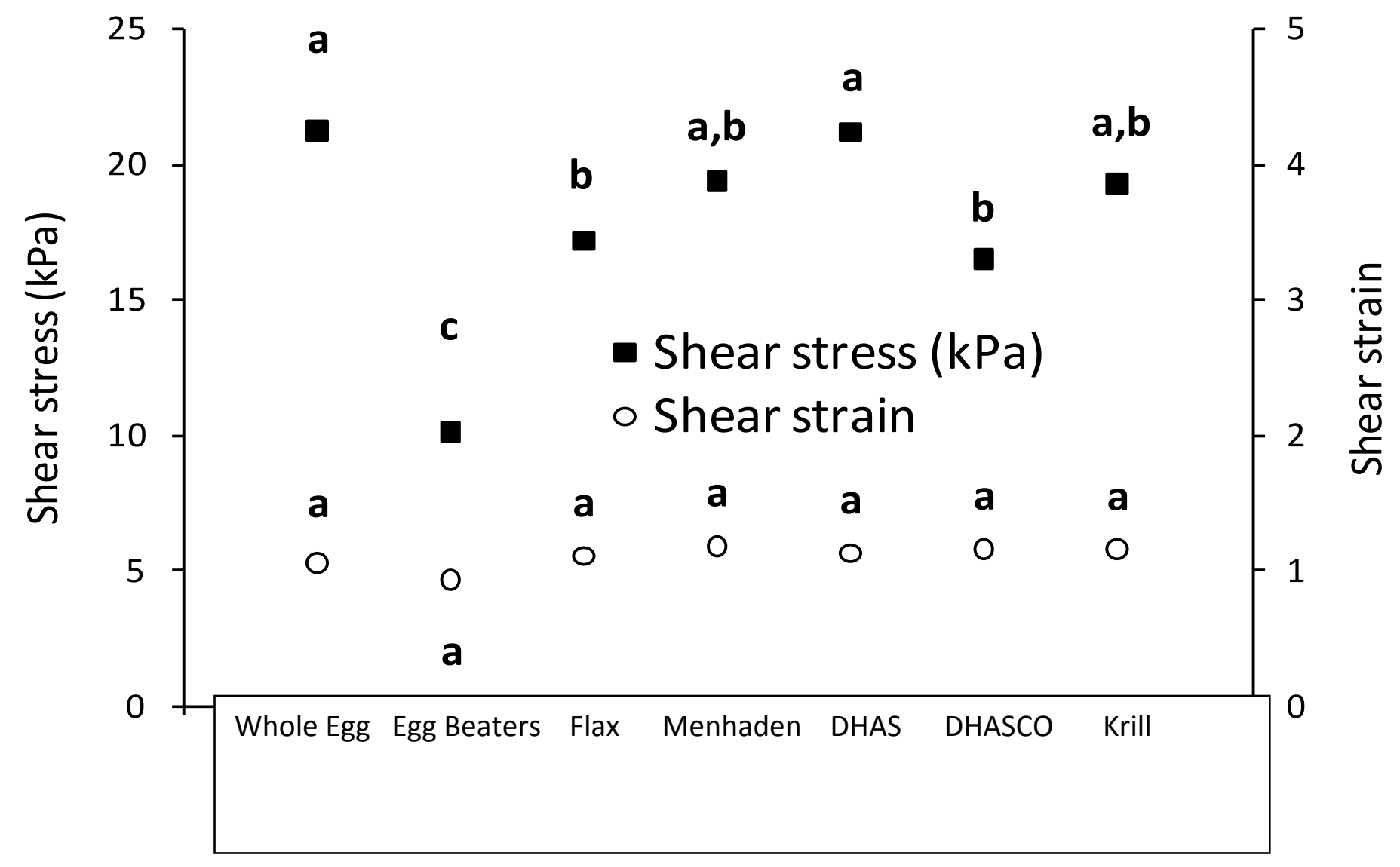

Figure 8. Shear stress* and shear strain* of cooked gels. Shear Stress and strain of cooked whole egg and egg beaters were compared to cooked experimental eggs developed with addition of flaxseed, menhaden, algae (DHAS and DHASCO), and krill oils.

* Data are given as mean values \pm standard deviation $(n=3)$. Different letters on the top of data points indicate significant differences (Fisher's Least Significant Difference, $\mathrm{P}<0.05$ ) between mean values within shear stress or shear strain. 


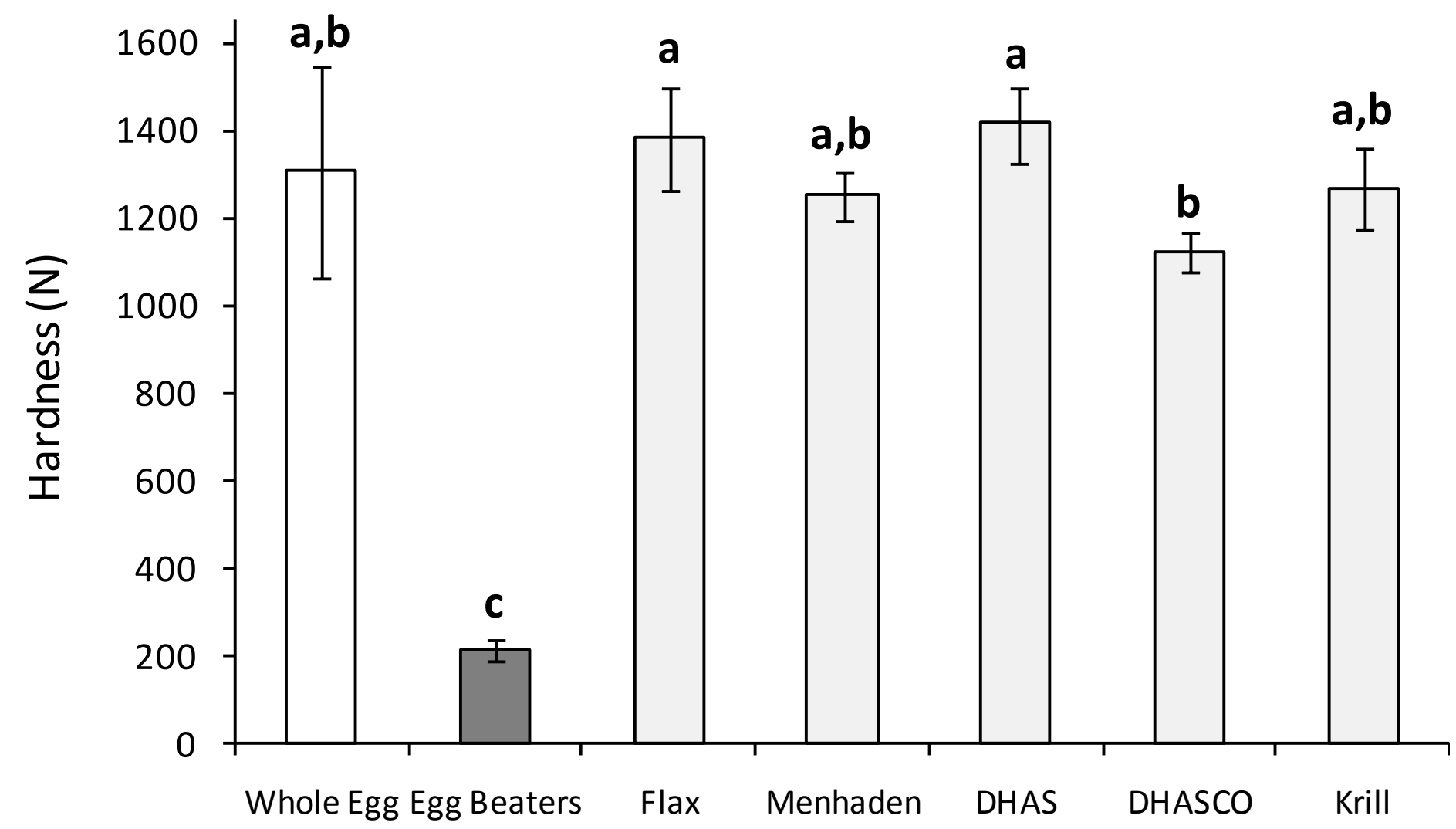

Figure 9. Hardness* (texture profile analysis) of cooked gels. Hardness of cooked whole egg and egg beaters was compared to cooked experimental eggs developed with addition of flaxseed, menhaden, algae (DHAS and DHASCO), and krill oils. * Data are given as mean values \pm standard deviation $(n=3)$. Different letters on the top of data bars indicate significant differences (Fisher's Least Significant Difference, $\mathrm{P}<0.05)$ between mean values. 
Table 1. Proximate analysis* of cooked gels. Proximate composition of cooked whole egg and egg beaters was compared to cooked experimental eggs developed with addition of flaxseed, menhaden, algae (DHAS and DHASCO), and krill oils.

\begin{tabular}{|c|c|c|c|c|c|c|c|}
\hline $\begin{array}{c}\text { Proximate } \\
\text { Composition }\end{array}$ & Whole Egg & $\begin{array}{c}\text { Egg } \\
\text { Beaters }\end{array}$ & Flax & Menhaden & $\begin{array}{c}\text { Algae } \\
\text { (DHAS) }\end{array}$ & $\begin{array}{c}\text { Algae } \\
\text { (DHASCO) }\end{array}$ & Krill \\
\hline $\begin{array}{c}\text { Moisture } \\
\text { (g/100g, wet basis) }\end{array}$ & $73.3 \pm 1.0 \mathrm{~b}$ & $87.5 \pm 0.7 \mathrm{a}$ & $73.2 \pm 2.1 \mathrm{~b}$ & $74.1 \pm 1.2 \mathrm{~b}$ & $73.2 \pm 1.1 \mathrm{~b}$ & $73.9 \pm 1.2 \mathrm{~b}$ & $73.4 \pm 1.9 \mathrm{~b}$ \\
\hline $\begin{array}{l}\text { Crude protein } \\
\text { (g/100g, dry basis) }\end{array}$ & $51.5 \pm 0.8 \mathrm{~b}$ & $78.8 \pm 0.7 \mathrm{a}$ & $51.9 \pm 1.9 \mathrm{~b}$ & $52.1 \pm 1.3 \mathrm{~b}$ & $52.2 \pm 0.8 \mathrm{~b}$ & $51.8 \pm 0.3 \mathrm{~b}$ & $51.8 \pm 0.3 b$ \\
\hline $\begin{array}{c}\text { Total fat } \\
\text { (g/100g, dry basis) }\end{array}$ & $42.3 \pm 2.6 \mathrm{a}$ & $2.6 \pm 0.9 \mathrm{~b}$ & $41.7 \pm 2.5 \mathrm{a}$ & $40.7 \pm 2.8$ a & $40.7 \pm 2.7 \mathrm{a}$ & $41.5 \pm 2.0 \mathrm{a}$ & $40.3 \pm 8.7 \mathrm{a}$ \\
\hline $\begin{array}{c}\text { Ash } \\
\text { (g/100g, dry basis) }\end{array}$ & $3.7 \pm 0.0 \mathrm{~b}$ & $6.8 \pm 0.3 \mathrm{a}$ & $6.6 \pm 0.3 \mathrm{a}$ & $6.9 \pm 0.3 \mathrm{a}$ & $6.8 \pm 0.2 \mathrm{a}$ & $6.7 \pm 0.3 \mathrm{a}$ & $6.8 \pm 0.2 \mathrm{a}$ \\
\hline
\end{tabular}

* Data are given as mean values \pm standard deviation $(n=3)$. Different letters within the same row indicate significant differences (Fisher's Least Significant Difference, $\mathrm{P}<0.05$ ) between mean values. 
Table 2. Essential amino acid (EAA) content* ( $\mathrm{g}$ of EAA/100 g of sample, dry basis) of cooked whole egg and egg beaters was compared to cooked experimental eggs developed with addition of flaxseed, menhaden, algae (DHAS and DHASCO), and krill oils. The recommended values of EAA content for adults and infants are provided for comparison.

* Data are given as mean values \pm standard deviation $(n=3)$. Different letters within the same row indicate significant differences (Fisher's Least Significant Difference, $\mathrm{P}<0.05$ ) between mean values.

\begin{tabular}{|c|c|c|c|c|c|c|c|c|}
\hline Essential Amino Acid & Whole Egg & Egg Beaters & Flax & Menhaden & DHAS & DHASCO & Krill & $\begin{array}{l}\text { FAO/WHO/UNU } \\
\text { Adults (infants) }\end{array}$ \\
\hline Histidine & $1.38 \pm 0.04 b$ & $2.18 \pm 0.09 a$ & $1.38 \pm 0.04 \mathrm{~b}$ & $1.25 \pm 0.01 b$ & $1.30 \pm 0.11 \mathrm{~b}$ & $1.32 \pm 0.08 b$ & $1.36 \pm 0.10 \mathrm{~b}$ & $1.6(2.6)$ \\
\hline Isoleucine & $2.95 \pm 0.10 b$ & $4.84 \pm 0.12 \mathrm{a}$ & $3.14 \pm 0.13 b$ & $3.00 \pm 0.10 \mathrm{~b}$ & $3.07 \pm 0.08 b$ & $3.05 \pm 0.07 b$ & $3.00 \pm 0.10 \mathrm{~b}$ & $1.3(4.6)$ \\
\hline Leucine & $4.59 \pm 0.14 b$ & $7.65 \pm 0.21 \mathrm{a}$ & $4.79 \pm 0.16 b$ & $4.53 \pm 0.04 \mathrm{~b}$ & $4.62 \pm 0.13 b$ & $4.68 \pm 0.11 b$ & $4.61 \pm 0.06 \mathrm{~b}$ & $1.9(9.3)$ \\
\hline Lysine & $3.80 \pm 0.11 b$ & $6.11 \pm 0.16 a$ & $3.80 \pm 0.11 b$ & $3.66 \pm 0.03 b$ & $3.70 \pm 0.12 b$ & $3.70 \pm 0.09 \mathrm{~b}$ & $3.79 \pm 0.09 \mathrm{~b}$ & $1.6(6.6)$ \\
\hline Methionine & $1.70 \pm 0.05 c$ & $3.18 \pm 0.09 a$ & $1.92 \pm 0.05 b$ & $1.86 \pm 0.01 \mathrm{bc}$ & $1.91 \pm 0.04 \mathrm{~b}$ & $1.88 \pm 0.08 \mathrm{bc}$ & $1.98 \pm 0.11 b$ & $1.7(4.2)$ \\
\hline Phenylalanine & $2.87 \pm 0.10 \mathrm{c}$ & $5.41 \pm 0.19 a$ & $3.44 \pm 0.15 b$ & $3.29 \pm 0.03 b$ & $3.27 \pm 0.10 \mathrm{~b}$ & $3.35 \pm 0.06 b$ & $3.27 \pm 0.09 \mathrm{~b}$ & $1.9(7.2)$ \\
\hline Threonine & $2.29 \pm 0.06 \mathrm{~b}$ & $3.72 \pm 0.13 a$ & $2.23 \pm 0.08 b$ & $2.14 \pm 0.04 \mathrm{~b}$ & $2.19 \pm 0.10 \mathrm{~b}$ & $2.19 \pm 0.06 \mathrm{~b}$ & $2.25 \pm 0.06 b$ & $0.9(4.3)$ \\
\hline Tryptophan & $0.84 \pm 0.02 b$ & $1.07 \pm 0.01 \mathrm{a}$ & $0.86 \pm 0.07 b$ & $0.83 \pm 0.05 \mathrm{~b}$ & $0.89 \pm 0.06 \mathrm{~b}$ & $0.89 \pm 0.04 b$ & $0.86 \pm 0.01 b$ & $0.5(1.7)$ \\
\hline Valine & $3.58 \pm 0.12 \mathrm{c}$ & $6.34 \pm 0.16 \mathrm{a}$ & $3.96 \pm 0.09 \mathrm{~b}$ & $3.85 \pm 0.03 b c$ & $3.87 \pm 0.10 b$ & $3.91 \pm 0.10 \mathrm{~b}$ & $3.92 \pm 0.06 b$ & $1.3(5.5)$ \\
\hline TEAA / TAA (\%) & $47.1 \mathrm{a}$ & $46.3 \mathrm{a}$ & $47.3 \mathrm{a}$ & $46.8 \mathrm{a}$ & $46.9 \mathrm{a}$ & $46.9 \mathrm{a}$ & $47.0 \mathrm{a}$ & \\
\hline
\end{tabular}


Table 3. Non-essential amino acid (NonEAA) content* (g of NonEAA/100 g of sample, dry basis) of cooked whole egg and egg beaters was compared to cooked experimental eggs developed with addition of flaxseed, menhaden, algae (DHAS and DHASCO), and krill oils. * Data are given as mean values \pm standard deviation $(\mathrm{n}=3)$. Different letters within the same row indicate significant differences (Fisher's Least Significant Difference, $\mathrm{P}<0.05$ ) between mean values.

\begin{tabular}{|c|c|c|c|c|c|c|c|}
\hline Non-Essential Amino Acid & Whole Egg & Egg Beaters & Flax & Menhaden & DHAS & DHASCO & Krill \\
\hline Alanine & $2.86 \pm 0.10 \mathrm{c}$ & $5.26 \pm 0.13 a$ & $3.17 \pm 0.09 b$ & $3.15 \pm 0.03 b$ & $3.18 \pm 0.09 b$ & $3.20 \pm 0.08 b$ & $3.17 \pm 0.06 b$ \\
\hline Arginine & $3.26 \pm 0.09 b$ & $5.02 \pm 0.13 a$ & $3.11 \pm 0.10 \mathrm{bc}$ & $3.01 \pm 0.04 c$ & $3.01 \pm 0.09 \mathrm{c}$ & $3.05 \pm 0.08 b c$ & $3.10 \pm 0.04 b c$ \\
\hline Aspartic acid & $5.06 \pm 0.15 b$ & $9.04 \pm 0.25 \mathrm{a}$ & $5.45 \pm 0.05 b$ & $5.35 \pm 0.06 \mathrm{~b}$ & $5.42 \pm 0.16 b$ & $5.41 \pm 0.14 b$ & $5.43 \pm 0.08 b$ \\
\hline Cysteine & $1.16 \pm 0.03 \mathrm{c}$ & $2.25 \pm 0.04 \mathrm{a}$ & $1.30 \pm 0.04 b$ & $1.28 \pm 0.03 \mathrm{~b}$ & $1.34 \pm 0.04 b$ & $1.25 \pm 0.06 \mathrm{bc}$ & $1.31 \pm 0.03 \mathrm{~b}$ \\
\hline Glutamic Acid & $6.04 \pm 0.16 \mathrm{c}$ & $11.26 \pm 0.25 \mathrm{a}$ & $6.90 \pm 0.24 b$ & $6.79 \pm 0.11 b$ & $6.91 \pm 0.18 b$ & $6.89 \pm 0.28 b$ & $6.67 \pm 0.16 b$ \\
\hline Glycine & $1.72 \pm 0.07 \mathrm{~b}$ & $3.09 \pm 0.07 \mathrm{a}$ & $1.83 \pm 0.08 b$ & $1.84 \pm 0.02 b$ & $1.86 \pm 0.05 b$ & $1.86 \pm 0.04 b$ & $1.87 \pm 0.03 b$ \\
\hline Proline & $1.78 \pm 0.05 b$ & $2.95 \pm 0.09 \mathrm{a}$ & $1.73 \pm 0.04 b$ & $1.68 \pm 0.04 b$ & $1.71 \pm 0.05 b$ & $1.68 \pm 0.04 b$ & $1.76 \pm 0.07 \mathrm{~b}$ \\
\hline Serine & $2.95 \pm 0.07 b$ & $4.69 \pm 0.17 \mathrm{a}$ & $2.82 \pm 0.13 b$ & $2.67 \pm 0.10 \mathrm{~b}$ & $2.67 \pm 0.18 b$ & $2.82 \pm 0.21 b$ & $2.85 \pm 0.07 b$ \\
\hline Tyrosine & $2.12 \pm 0.05 b$ & $3.39 \pm 0.11 \mathrm{a}$ & $2.17 \pm 0.12 b$ & $2.10 \pm 0.02 b$ & $2.03 \pm 0.08 b$ & $2.14 \pm 0.04 b$ & $2.08 \pm 0.08 \mathrm{~b}$ \\
\hline
\end{tabular}


Table 4. Fatty acid ratios of cooked whole egg was compared to cooked experimental eggs developed with addition of flaxseed,menhaden, algae (DHAS and DHASCO), and krill oils. * Data are given as mean values \pm standard deviation $(\mathrm{n}=3)$. Different letters within the same row indicate significant differences (Fisher's Least Significant Difference, $\mathrm{P}<0.05$ ) between mean values.

\begin{tabular}{|c|c|c|c|c|c|c|}
\hline FA Ratio & Whole Egg & Flax & Menhaden & DHAS & DHASCO & Krill \\
\hline 「 & & 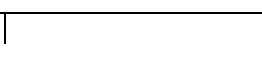 & & & & \\
\hline$n-6 / n-3$ & $2.64 \pm 0.226 \mathrm{a}$ & $0.51 \pm 0.005 b$ & $0.14 \pm 0.001 \mathrm{c}$ & $0.07 \pm 0.002 \mathrm{c}$ & $0.09 \pm 0.016 \mathrm{c}$ & $0.12 \pm 0.01 \mathrm{c}$ \\
\hline UFA / SFA & $1.81 \pm 0.024 \mathrm{c}$ & $7.62 \pm 0.667 \mathrm{a}$ & $2.01 \pm 0.014 \mathrm{c}$ & $2.09 \pm 0.118 \mathrm{c}$ & $4.56 \pm 0.210 b$ & $3.86 \pm 0.052 b$ \\
\hline
\end{tabular}


Table 5. Tristimulus color values* $\left(\mathrm{L}^{*} \mathrm{a}^{*} \mathrm{~b}^{*}\right)$ of cooked gels. Color values of cooked whole egg and egg beaters were compared to cooked experimental eggs developed with addition of flaxseed, menhaden, algae (DHAS and DHASCO), and krill oils.

\begin{tabular}{cccccccc}
$\begin{array}{c}\text { Color } \\
\text { Value }\end{array}$ & Whole Egg & $\begin{array}{c}\text { Egg } \\
\text { Beaters }\end{array}$ & Flax & Menhaden & $\begin{array}{c}\text { Algae } \\
\text { (DHAS) }\end{array}$ & $\begin{array}{c}\text { Algae } \\
\text { (DHASCO) }\end{array}$ & Krill \\
\hline L* & $87.2 \pm 0.9 \mathrm{~cd}$ & $92.7 \pm 0.8 \mathrm{a}$ & $88.4 \pm 0.4 \mathrm{~b}$ & $88.0 \pm 0.3 \mathrm{bc}$ & $87.7 \pm 0.2 \mathrm{bcd}$ & $86.6 \pm 0.8 \mathrm{~d}$ & $73.1 \pm 0.6 \mathrm{e}$ \\
$\mathbf{a}^{*}$ & $-4.3 \pm 0.2 \mathrm{f}$ & $-3.1 \pm 0.1 \mathrm{e}$ & $0.9 \pm 0.1 \mathrm{~d}$ & $1.1 \pm 0.1 \mathrm{~d}$ & $1.9 \pm 0.1 \mathrm{c}$ & $3.7 \pm 0.4 \mathrm{~b}$ & $37.5 \pm 1.1 \mathrm{a}$ \\
& & & & & & & \\
b* & $27.9 \pm 0.6 \mathrm{~d}$ & $23.8 \pm 2.1 \mathrm{e}$ & $43.1 \pm 0.2 \mathrm{c}$ & $44.9 \pm 0.4 \mathrm{c}$ & $49.0 \pm 1.2 \mathrm{~b}$ & $52.0 \pm 2.0 \mathrm{a}$ & $51.0 \pm 2.2 \mathrm{ab}$
\end{tabular}

* Data are given as mean values \pm standard deviation $(n=3)$. Different letters within the same row indicate significant differences (Fisher's Least Significant Difference, $\mathrm{P}<0.05$ ) between mean values. 
Table 6. Texture profile analysis* (TPA) of cooked gels. Texture profile of cooked whole egg and egg beaters was compared to cooked experimental eggs developed with addition of flaxseed, menhaden, algae (DHAS and DHASCO), and krill oils.

\begin{tabular}{cccccccc}
\cline { 2 - 7 } $\begin{array}{c}\text { TPA } \\
\text { Parameter }\end{array}$ & Whole Egg & $\begin{array}{c}\text { Egg } \\
\text { Beaters }\end{array}$ & Flax & Menhaden & $\begin{array}{c}\text { Algae } \\
\text { (DHAS) }\end{array}$ & $\begin{array}{c}\text { Algae } \\
\text { (DHASCO) }\end{array}$ & Krill \\
\hline Springiness & $2.04 \pm 0.01 \mathrm{a}$ & $0.83 \pm 0.29 \mathrm{~b}$ & $1.92 \pm 0.24 \mathrm{a}$ & $1.75 \pm 0.13 \mathrm{a}$ & $1.83 \pm 0.22 \mathrm{a}$ & $1.84 \pm 0.23 \mathrm{a}$ & $1.83 \pm 0.22 \mathrm{a}$ \\
Cohesiveness & $0.61 \pm 0.03 \mathrm{a}$ & $0.27 \pm 0.04 \mathrm{~b}$ & $0.65 \pm 0.04 \mathrm{a}$ & $0.63 \pm 0.03 \mathrm{a}$ & $0.65 \pm 0.02 \mathrm{a}$ & $0.63 \pm 0.03 \mathrm{a}$ & $0.65 \pm 0.04 \mathrm{a}$ \\
& & & & & & & \\
Gumminess & $981 \pm 349 \mathrm{a}$ & $78 \pm 19 \mathrm{~b}$ & $992 \pm 64 \mathrm{a}$ & $810 \pm 29 \mathrm{a}$ & $919 \pm 183 \mathrm{a}$ & $747 \pm 89 \mathrm{a}$ & $846 \pm 85 \mathrm{a}$ \\
Chewiness & $1596 \pm 456 \mathrm{a}$ & $120 \pm 20 \mathrm{~b}$ & $1519 \pm 171 \mathrm{a}$ & $1325 \pm 50 \mathrm{a}$ & $1640 \pm 133 \mathrm{a}$ & $1307 \pm 315 \mathrm{a}$ & $1487 \pm 299 \mathrm{a}$ \\
Resilience & $0.32 \pm 0.03 \mathrm{a}$ & $0.18 \pm 0.04 \mathrm{~b}$ & $0.33 \pm 0.03 \mathrm{a}$ & $0.33 \pm 0.02 \mathrm{a}$ & $0.33 \pm 0.02 \mathrm{a}$ & $0.30 \pm 0.03 \mathrm{a}$ & $0.32 \pm 0.03 \mathrm{a}$
\end{tabular}

* Data are given as mean values \pm standard deviation $(n=3)$. Different letters within the same row indicate significant differences (Fisher's Least Significant Difference, $\mathrm{P}<0.05$ ) between mean values. 